\title{
Corporate Resilience to Banking Crises: The Roles of Trust and Trade Credit
}

\author{
Ross Levine, Chen Lin, and Wensi Xie*
}

\begin{abstract}
Are firms more resilient to systemic banking crises in economies with higher levels of social trust? Using firm-level data in 34 countries from 1990 through 2011, we find that liquidity-dependent firms in high-trust countries obtain more trade credit and suffer smaller drops in profits and employment during banking crises than similar firms in low-trust economies. The results are consistent with the view that when banking crises block the normal bank-lending channel, greater social trust facilitates access to informal finance, cushioning the effects of these crises on corporate profits and employment.
\end{abstract}

\section{Introduction}

Systemic banking crises are costly, common, and heavily researched. Boyd, Kwak, and Smith (2005), Kroszner, Laeven, and Klingebiel (2007), Claessens, Tong, and Wei (2012), and others show that banking crises shrink output and employment. Reinhart and Rogoff (2009) document the ubiquitousness of financial crises throughout history, and Laeven and Valencia (2013) find that most countries experienced a systemic banking crisis between 1970 and 2011. Unsurprisingly, therefore, an active line of research examines the causes of banking crises (e.g., see recent reviews by Claessens, Kose, Laeven, and Valencia (2014) and Laeven (2011)).

What has received less attention is the resilience of firms, and hence economies, to systemic banking crises. Although many countries experience

*Levine (corresponding author), rosslevine@berkeley.edu, University of California Berkeley Haas School of Business, Milken Institute, and National Bureau of Economic Research (NBER); Lin, chenlin1@hku.hk, University of Hong Kong Faculty of Business and Economics; and Xie, wensixie@cuhk.edu.hk, Chinese University of Hong Kong CUHK Business School. We thank Franklin Allen, Thorsten Beck, Craig Doidge, Jefferson Duarte (the referee), Andrew Ellul, Itay Goldstein, Gary Gorton, Jun-Koo Kang, Yoonha Kim, Florencio Lopez-de-Silanes, Michelle Lowry, Paul Malatesta (the editor), Luigi Zingales, and the seminar participants at the Wharton School for their helpful comments and suggestions. Xie thanks Franklin Allen for hosting her visit at the Wharton Financial Institutions Center. Part of the research was conducted during her visit at Wharton as a Fulbright scholar. 
crises, not all experience similar reductions in output and employment. Levine, Lin, and Xie (2016) show that well-developed stock markets mitigate the adverse effects of banking crises by providing an alternative source of financing when crises curtail the flow of bank credit to firms. But other factors might also shape the ability of firms to obtain financing during systemic banking crises.

In this article, we examine whether social trust affects i) the ability of firms to obtain financing through informal channels when crises reduce the flow of bank loans to firms and ii) the resilience of corporate profits and employment to systemic banking crises. As defined by Fukuyama ((1995), p. 27) and Putnam ((2000), p. 19), social trust means the expectations within a community that people will behave in honest and cooperative ways and the extent to which human interactions are governed by the norms of reciprocity and trustworthiness. By informal finance, we mean credit provision that occurs beyond the scope of a country's formal financial and regulatory institutions. For example, firms often receive trade credit that does not involve collateral or promissory notes subject to formal judicial enforcement mechanisms (Ayyagari, Demirgüç-Kunt, and Maksimovic (2010)). Trade credit represents a large proportion of debt financing, accounting for $25 \%$ of the average firm's total debt liabilities in our sample of over 3,500 firms across 34 countries from 1990 to 2011.

Existing research suggests how social trust could enhance corporate resilience to systemic banking crises. First, when a systemic banking crisis impedes the normal bank-lending channel (Cornett, McNutt, Strahan, and Tehranian (2011)), access to trade credit could partially offset the reduction in bank loans and ameliorate the impact of the crisis on corporate profits and employment (Campello, Graham, and Harvey (2010)). Indeed, Garcia-Appendini and Montoriol-Garriga (2013) show that the 2007-2008 banking crisis triggered a surge in between-firm liquidity provision. Second, social trust could facilitate access to trade credit during a banking crisis. Karlan (2005) shows that people who view their communities as more trustworthy are more likely to lend money and pay back loans even when there are no formal enforcement mechanisms in place. Although firms might prefer bank loans (Ayyagari et al. (2010), Ayyagari, Demirgüç-Kunt, and Maksimovic (2011)) and choose banks as their primary liquidity providers during normal times (Gatev, Schuermann, and Strahan (2009)), high social trust can increase firms' access to trade credit when bank loans are unavailable (Allen, Qian, and Qian (2005)). ${ }^{1}$

Using a difference-in-differences methodology, we first assess the relation between social trust and firms' use of trade credit, profitability, and employment during systemic banking crises. We use a sample of about 3,600 manufacturing firms across 34 countries over the years from 1990 through 2011. Data on trade credit received, profitability, employment, and other firm-level information come from Worldscope. Our key explanatory variable is the interaction term between a measure of social trust (TRUST) and a crisis dummy that equals 1 in the start

${ }^{1}$ As shown by Carlin, Dorobantu, and Viswanathan (2009), the relation between trust and formal rules and regulations is complex, such that they might be complements under some conditions and substitutes under other conditions. Thus, social trust can also affect bank lending. In this article, we evaluate the particular condition of a banking crisis and assess whether social trust mitigates the adverse effects of a banking crisis on the economy. 
year of a systemic banking crisis and remains 1 for the 3 years after the crisis (CRISIS). To date systemic banking crises, we rely on Laeven and Valencia (2013). To measure social trust, we follow previous studies (e.g., La Porta, Lopezde-Silanes, Shleifer, and Vishny (1997a)) and compute the percentage of survey respondents who answer "most people can be trusted" in response to the question in World Values Survey (WVS), "Generally speaking, would you say that most people can be trusted, or that you can't be too careful in dealing with people?" We measure TRUST 3 years before the start of a country's systemic banking crisis. We interpret greater values of the trust measure as suggesting that suppliers of trade credit are more confident about the trustworthiness of the demanders of such credit. If the key interaction term (TRUST $\times$ CRISIS) enters positively, this suggests that, on average, social trust mitigates the fall in trade-credit financing, firm profitability, and firm employment during systemic banking crises.

We then explore whether the relation between social trust and firm trade credit, profits, and employment differs across industries in a theoretically predictable manner. In particular, because trade credit is a closer substitute for a firm's short-run liquidity needs than it is for long-term capital investments (Klapper, Laeven, and Rajan (2012)), the resilience-enhancing effects of social trust should be greatest among firms that depend heavily on liquid funds. Thus, we not only assess whether corporations are more resilient to banking crises in highertrust countries, but we also examine differences in the cross-industry resilience to such crises. To measure an industry's short-run liquidity needs, we follow Raddatz (2006) and use the proportion of working capital financed by ongoing sales; higher values indicate greater dependence on short-run liquidity.

The empirical findings are consistent with the predictions that i) social trust facilitates access to trade credit during systemic banking crises, ii) social trust dampens the harmful effects of the crisis on firm profits and employment, and iii) the resilience-enhancing effects of social trust are largest among firms that rely heavily on liquid funds. The analyses control for both firm fixed effects to condition out all time-invariant, firm-specific features that might account for a firm's resilience to a banking crisis and year effects to control for the evolution of corporate performance, access to trade credit, and resilience to shocks. The regressions also control for an assortment of time-varying and firm characteristics discussed later in the article. We discover that firms in higher-trust countries receive more trade-credit financing and suffer smaller reductions in profits and employment than firms in lower-trust countries during systemic banking crises. Moreover, the relation between social trust and trade credit, profitability, and employment is more pronounced among industries that depend heavily on external liquidity provision. The evidence is consistent with the view that social trust improves the resiliency of firms to banking crises.

The connections between social trust and corporate financing, profits, and employment are economically meaningful. Consider a hypothetical "average" country that has the sample average value of social trust $(0.328)$ and a "high-trust" country with a TRUST value that is 1 standard deviation higher than the sample average (0.496), and set the other country characteristics constant at their sample average values for both hypothetical countries. The coefficient estimates from our baseline regressions suggest that in liquidity-dependent firms, trade-credit 
financing drops by $43 \%$ less in the high-trust country than it falls in the average country during a systemic banking crisis. In terms of firm performance and employment, the coefficient estimates indicate that corporate profits drop by $52 \%$ less and firm employment drops by $18 \%$ less in the high-trust country than they drop in the average country during a crisis.

We address several potential challenges to identifying the impact of social trust on corporate resilience to banking crises. First, if social trust shapes the size of systemic banking crises, then our findings might reflect differences in the severity of crises, not the resilience of firms to similarly sized banking crises. Our analyses, however, suggest that the results do not simply reflect the impact of social trust on crisis size. In particular, trust does not explain cross-country differences in the sizes of banking crises, as measured by the reduction of bank credit. Moreover, all of the results in the article hold when controlling for the size of the banking crisis or other features of the economy that could account for differences in the severity of the crisis, such as the size of banks, the level of stock market development, and the overall level of legal and institutional development.

Second, social trust could be correlated with national policies and institutions that account for differences in corporate performance following banking crises. For example, if social trust is highly correlated with economic development, bank and stock market development, the degree to which the formal legal system protects creditors and shareholders, the effectiveness of the legal system in enforcing contracts, and the overall level of institutional development, this could hinder our ability to draw sharp inferences about social trust. Consequently, our baseline regressions control for the interaction between the crisis dummy variable and i) gross domestic product (GDP) per capita, ii) the size of the financial intermediary sector, iii) stock market capitalization as a share of GDP, iv) the contraction of bank credit during the crisis, v) the legal rights of creditors, and vi) the legal protection of minority shareholders. Furthermore, we extend these analyses and also control for the interaction between the crisis dummy and i) a measure of the rule of law that corresponds to the extent to which agents have confidence in the operation of the formal mechanisms for enforcing laws and contracts and ii) a measure of overall institutional quality that equals the first principal component of property rights, voice of accountability, political stability and absence of violence, government effectiveness, regulatory quality, rule of law, and control of corruption. In addition, social trust might be correlated with employment protection laws and trust in government that shape the response of firms to a banking crisis. For instance, a more rigid labor market might make it more costly for companies to adjust labor forces, and if managers in an economy believe the government will resolve the banking crisis, they might lay off fewer workers. To further isolate the effects of social trust on the resilience of corporate employment and profits, we account for the interaction between the crisis dummy and i) an index of labor market regulations and ii) a measure of the confidence that people have in the government. When controlling for all of these interaction terms, firm and year fixed effects, and time-varying firm traits, such as firm size, long-term debt, and Tobin's Q, we continue to find that social trust has a statistically significant and economically large association with corporate resilience to banking crises only in liquidity-dependent industries. This is consistent with existing research 
suggesting that trade credit relies more on social trust (e.g., Allen et al. (2005), Ayyagari et al. (2010)), whereas formal financial arrangements rely more on legal institutions (e.g., La Porta, Lopez-de-Silanes, Shleifer, and Vishny (1997b), (1998)).

A third challenge to identifying the impact of social trust on corporate resilience to banking crises involves differential trends across countries, industries, and firms. Specifically, firms in high-trust countries might have different trends in performance from those in low-trust countries, firms in high-liquidity-dependent industries might have different trends in performance from those in low-liquiditydependent industries in the same country, and firms in high- (and low-) liquiditydependent industries in high-trust countries might have different trends in firm performance from corresponding firms in low-trust countries. We address these concerns by adding the following to the explanatory variables described previously: i) country-level time trends for 34 countries in our sample to account for potential differences in time trends across countries, ii) country-industry time trends for 1,151 country-industry pairs to account for potential differences in time trends across industries in different countries, or iii) firm-level time trends for 3,603 sample firms to control for potential differences in time trends across individual firms. The core results hold.

Fourth, there might be concerns that banking crises influence trust, which could hinder our ability to draw sharp inferences from the coefficient estimates on the interaction term, TRUST $\times$ CRISIS. We address this concern by i) using preexisting measures of trust that are calculated before each country's systemic banking crisis and while controlling for country and firm fixed effects, ii) showing that the results hold when measuring TRUST at the beginning of the entire sample period, and iii) showing that systemic banking crises do not explain changes in trust in our sample. This is consistent with the view that trust, or more broadly embedded social norms and beliefs, changes very slowly in the long run and exhibits high persistence across generations (Williamson (2000)). In line with this view, Nunn and Wantchekon (2011) show that African descendants of those heavily exposed to the slave trades almost 100 years ago display low trust of others today. They stress that people's internal beliefs and values that tend to be transmitted over generations are essential to the mechanism through which historical slave trades affect current interpersonal trust. Focusing on eight countries in Europe, Tabellini (2010) finds that the distant history of education and urbanization in a region fosters the formation of social trust, which propagates over time and influences economic outcomes today. Guiso, Sapienza, and Zingales (2016) review the recent works on the short- and long-run persistence of social trust and show the long-term persistence of social capital in Italy.

This study relates to several strands of research. First, it complements a large number of studies of how social trust and, more generally, social capital influence economic behavior. Glaeser, Laibson, Scheinkman, and Soutter (2000) discover that an individual's broad views of trust, as garnered from attitudinal surveys, predict trustworthy behavior within experimental settings. Karlan (2005) shows that attitudes toward trust influence an individual's willingness to lend based on the trustworthiness of the borrower and to repay loans even when such loans are not enforceable in court. Using transaction-level data from a U.S. peer-to-peer 
lending platform, Duarte, Siegel, and Young (2012) show that borrowers who appear more trustworthy are more likely to obtain a loan. More broadly, Knack and Keefer (1997) show that social trust is associated with faster economic growth, and La Porta et al. (1997a) document the link between trust and corporate performance. Our article shows that social trust influences corporate resilience to systemic banking crises.

Second, our study helps reconcile the mixed findings on the relation between trade and bank credit. In a study of the recent U.S. financial crisis, GarciaAppendini and Montoriol-Garriga (2013) show that nonfinancial firms extend substantial trade credit to their customers when bank credit is scarce. However, in a study of six emerging economies that experienced banking crises, Love, Preve, and Sarria-Allende (2007) find that trade credit does not compensate much for the contraction in bank credit due to crises. Focusing on the financing patterns of 48 countries in 1999, Beck, Demirgüç-Kunt, and Maksimovic (2008)) show that although firms that are financially constrained can partially substitute trade for bank finance, the availability of trade credit is more limited in developing economies. Our findings suggest that cross-country differences in social trust shape crosscountry differences in the degree to which firms substitute trade credit for bank credit during banking crises.

Third, our findings add to a growing literature on finance and employment. By allocating resources efficiently, well-developed financial markets can improve labor markets (Pagano and Volpin (2008), Beck, Levine, and Levkov (2010)). Our findings are consistent with the view that social trust helps mitigate the impact of banking crises on unemployment by making it easier for firms to access alternative, informal sources of financing.

The rest of this article proceeds as follows: Section II defines the data, Section III describes the empirical methodology, Section IV presents the empirical results on social trust and financing during systemic banking crises, Section V gives the results on trust and firm profits and employment during crises, and Section VI concludes.

\section{Data}

\section{A. Sample}

Our initial sample begins with the 65 countries that both have data on social trust in the WVS and experienced at least one systemic banking crisis during the period from 1990 through 2011 according to Laeven and Valencia (2013). For this initial sample, we obtain firm-level data from the Thomson Reuters Worldscope database. We then further restrict the sample of countries and firms based on the following: First, we focus on publicly listed firms in U.S. manufacturing industries (Standard Industrial Classification (SIC) codes between 2000 and 3999). Second, a firm needs to have complete financial information in the Worldscope database over the 7-year crisis window, $[t-3$, $t+3$ ], where $t$ equals the start year of a systemic crisis as defined by Laeven and Valencia (2013). Third, we eliminate observations with negative assets, negative book equity, or negative cost of goods sold. Fourth, a country needs to have at 
least three firms with complete information. Fifth, a country must be covered in i) Djankov, La Porta, Lopez-de-Silanes, and Shleifer (2008) so that we have information on shareholder protection laws and in ii) Djankov, McLiesh, and Shleifer (2007) so that we have information on the creditor protection laws. Finally, we exclude firms in the United States from our analyses because we rely on the U.S. firms to benchmark industries.

These selection criteria yield a sample of over 3,500 firms across 34 countries over the period from 1990 through 2011. In total, the sample contains over 22,500 firm-year observations. The average firm in our sample has 6 years of data. The Appendix describes all of variables in detail.

\section{B. Social Trust Measure}

The WVS aims to measure the "beliefs, values, and motivations of people" across countries and has been widely used in prior studies to capture cross-country variations in trust (e.g., Knack and Keefer (1997), La Porta et al. (1997a)). From the WVS, we use the answer to the following survey question to measure trust:

Generally speaking, would you say that most people can be trusted, or that you can't be too careful in dealing with people?

The WVS offers three possible responses: i) most people can be trusted; ii) you can't be too careful in dealing with other people; and iii) I don't know. Following La Porta et al. (1997a), we calculate TRUST within a country as the percentage of respondents who reply that most people can be trusted.

Critically, we use the precrisis level of trust in each country. Specifically, given that the WVS has been conducted close to every 5 years since 1990, we use TRUST in period $t-3$ or the earliest available year before $t$, where $t$ represents the start year of a banking crisis in the country. Summary statistics in Table 1 show that the average level of trust in our sample is 0.328 with a standard deviation of 0.168. Denmark has the highest level of trust, 0.665, whereas the Philippines and Turkey have the lowest, 0.055 (see Table IA1 in the Internet Appendix, available at www.jfqa.org).

To further alleviate concerns that crises influence trust, we perform two robustness tests. First, we find that crises do not explain trust. To do this, we use the most relevant wave of the WVS to assign the value of trust in each period for a country to test whether the systemic banking crises are associated with significant changes in trust. As shown in Internet Appendix Table IA11, we find no evidence that trust changes following a banking crisis. ${ }^{2}$ This is consistent with the view that norms of social trust persist over time (Williamson (2000)). Second, we show that all of the results hold when using the initial value of trust in our sample period

\footnotetext{
${ }^{2}$ This result is robust to alternative ways of linking data from the six waves of the WVS to particular years. The WVS collects the trust data in six waves, 1981-1984, 1990-1994, 1995-1998, 1999-2004, 2005-2009, and 2010-2014, and we use these data to assign a value of trust to the relevant years over the 7-year crisis window, $[t-3, t+3]$, for each country. Because a wave can span several years over a country's $t-3$ to $t+3$ period, we consider alternative ways of linking the WVS to particular years. For example, we use early waves for the years before a crisis and/or later waves for the years after the crisis. In no case do we find that crises account for change in trust in a statistically significant manner.
} 
TABLE 1

Summary Statistics

For the variables listed in the first column, Table 1 provides the number of observations $(N)$, the average value (Mean), the standard deviation (Std. Dev.), the minimum value (Min.), the maximum value (Max.), and the values at the 25th (P25), 50th (P50), and 75th (P75) percentiles, respectively. Each of the variables is defined in the Appendix.

\begin{tabular}{|c|c|c|c|c|c|c|c|c|}
\hline Variable & $N$ & Mean & $\begin{array}{l}\text { Std. } \\
\text { Dev. }\end{array}$ & Min. & P25 & P50 & P75 & Max. \\
\hline TRUST & 34 & 0.328 & 0.168 & 0.055 & 0.223 & 0.313 & 0.415 & 0.665 \\
\hline GDP_PER_CAPITA & 34 & 9.211 & 1.455 & 5.999 & 8.295 & 9.570 & 10.492 & 10.854 \\
\hline FINAÑCIAL_INSTITUTION_DEVELOPMENT & 34 & 0.807 & 0.511 & 0.121 & 0.323 & 0.737 & 1.132 & 1.997 \\
\hline STOCK_MĀRKET_DEVELŌPMENT & 34 & 0.579 & 0.592 & 0.049 & 0.193 & 0.416 & 0.774 & 2.792 \\
\hline PRIVATE_CREDIT_CONTRACTION & 34 & 0.287 & 0.226 & 0.018 & 0.101 & 0.217 & 0.468 & 0.780 \\
\hline ANTI_SELF_DEALING & 34 & 0.440 & 0.219 & 0.081 & 0.282 & 0.425 & 0.544 & 0.950 \\
\hline CREDITOR_RIGHTS & 34 & 2.059 & 1.099 & 0.000 & 1.000 & 2.000 & 3.000 & 4.000 \\
\hline RULE_OF_LAW & 34 & 0.698 & 0.967 & -1.081 & -0.005 & 0.764 & 1.623 & 1.945 \\
\hline INSTITUTIONONAL_QUALITY & 34 & -0.088 & 2.514 & -4.833 & -2.623 & 0.102 & 2.499 & 3.277 \\
\hline CRISIS & 237 & 0.586 & 0.494 & 0.000 & 0.000 & 1.000 & 1.000 & 1.000 \\
\hline TRADE_CREDIT_FINANCING/COGS & 22,599 & 0.007 & 0.076 & -0.317 & -0.019 & 0.005 & 0.031 & 0.366 \\
\hline TRADE_CREDIT_FINANCING/TOTAL_ASSETS & 22,775 & 0.008 & 0.047 & -0.123 & -0.011 & 0.003 & 0.021 & 0.256 \\
\hline EQUITY_ISSUANCE & 19,892 & 0.031 & 0.159 & -0.289 & -0.006 & 0.001 & 0.019 & 1.305 \\
\hline DEBT_ISSUANCE & 21,776 & 0.021 & 0.111 & -0.232 & -0.025 & 0.000 & 0.042 & 0.618 \\
\hline EBIT & 23,177 & 0.057 & 0.120 & -0.527 & 0.018 & 0.051 & 0.103 & 0.493 \\
\hline NET_INCOME & 23,493 & 0.021 & 0.102 & -0.539 & 0.001 & 0.021 & 0.059 & 0.352 \\
\hline CASH_FLOW & 22,136 & 0.063 & 0.109 & -0.486 & 0.025 & 0.061 & 0.109 & 0.429 \\
\hline FIRM_EMPLOYMENT & 20,982 & 7.078 & 1.841 & 0.000 & 5.969 & 6.958 & 8.167 & 13.126 \\
\hline FIRM_SIZE & 23,386 & 12.736 & 1.925 & 7.773 & 11.479 & 12.645 & 13.902 & 17.929 \\
\hline LONG_TERM_DEBT & 23,386 & 0.121 & 0.117 & 0.000 & 0.014 & 0.096 & 0.195 & 0.523 \\
\hline TOBINS_Q & 23,386 & 0.255 & 0.442 & -0.664 & -0.015 & 0.185 & 0.441 & 1.891 \\
\hline LIQUIDITY_NEEDS & 2,079 & 0.151 & 0.053 & 0.012 & 0.116 & 0.147 & 0.182 & 0.364 \\
\hline INVENTORIES/COGS & 2,079 & 0.228 & 0.092 & 0.021 & 0.169 & 0.211 & 0.288 & 0.650 \\
\hline TRADE_CREDIT_RELIANCE & 2,079 & 0.404 & 0.239 & 0.055 & 0.276 & 0.361 & 0.464 & 2.717 \\
\hline
\end{tabular}

(i.e., the value in 1990 for all countries). Internet Appendix Table IA12 provides these results.

\section{Systemic Banking Crises}

We use the database compiled by Laeven and Valencia (2013) to determine the start year of each crisis in a country. It is a comprehensive database of banking crisis episodes during the period from 1970 through 2011 across more than 100 countries. They define the start year of a systemic banking crisis as the first year when the overall banking system exhibits significant symptoms of financial distress, including bank runs and bank liquidations, and when the government intervenes in the banking sector in response to significant losses in the banking sector. Importantly, the crises episodes based on Laeven and Valencia (2013) identify periods with financial distress in the entire banking sector, as opposed to problems with individual banks.

For each crisis event, we focus on a 7-year window, $[t-3, t+3]$, centered on the start year of the crisis $t$, during which $[t-3, t-1]$ is defined as the precrisis period, and $[t, t+3]$ is defined as the crisis period. We define CRISIS as a dummy variable that equals 1 if a country is in a crisis period and 0 during the precrisis period. Internet Appendix Table IA1 lists the start years of systemic banking crises for the 34 countries. As shown, 18 countries suffered systemic crises during the recent global financial crisis, and 6 had crises during the East Asian financial crisis. Over the years from 1990 through 2011, all of the countries in our sample had one systemic crisis except Argentina, which had two. In dating the two Argentine crises, we follow Kroszner et al. (2007). The start years of the first and second banking crisis in 
Argentina are 1995 and 2001, respectively. We define the precrisis period for both crises as [1992, 1994]. The crisis period for the first crisis is [1995, 1998], and it is [2001, 2004] for the second crisis. The article's conclusions hold when excluding Argentina. Furthermore, we also conduct all of the article's analyses using a narrower window $[t-1, t+1]$. All of the results hold.

\section{Firm-Level Variables}

Using data from Worldscope, we construct measures of trade credit. We begin with the balance sheet item ACCOUNT_PAYABLE, which equals the amount of goods and services that a purchasing firm receives from suppliers before paying for them. ACCOUNT_PAYABLE is not a formal legal instrument, and the purchasing firm does not sign a promissory note. Although ACCOUNT_PAYABLE is a stock entry on the firm's balance sheet, TRADE_CREDIT_FINANCING equals the change in ACCOUNT_PAYABLE during a particular time period. TRADE_CREDIT_FINANCING is positive if the firm receives more goods and services than it pays. Trade-credit financing will be negative if the firm not only pays for the goods and services that it receives, but it also pays down at least some of the stock of accounts payable.

Based on these components, we construct and examine two measures of trade credit: i) TRADE_CREDIT_FINANCING/COGS equals TRADE_ CREDIT_FINANCING divided by the cost of goods sold (COGS) during the period, and ii) TRADE_CREDIT_FINANCING/TOTAL_ASSETS equals TRADE_CREDIT_FINANCING divided by the book value of total assets at the beginning of period $t$. Table 1 provides summary statistics for these variables. TRADE_CREDIT_FINANCING/COGS has a sample mean of 0.007 and a standard deviation of 0.076 , meaning that the average increase in trade credit obtained from the suppliers equals 0.7 percentage points of a firm's cost of goods sold, with a corresponding standard deviation of 7.6 percentage points.

Besides these informal financing measures, we also examine two measures of formal financing. Following Baker, Stein, and Wurgler (2003), we infer the amount of new equity issuance from a firm's balance sheet items, and we define EQUITY_ISSUANCE as the change in the book value of common equity plus the change in deferred taxes minus the change in retained earnings during year $t$, scaled by the book value of total asset at the beginning of period $t$. DEBT_ISSUANCE equals the change in TOTAL_DEBT during a particular year $t$, scaled by total assets at the beginning of year $t$. TOTAL_DEBT is the sum of short-term debt and long-term debt excluding capitalized leases. Table 1 shows that EQUITY_ISSUANCE ranges from -0.289 to 1.305 with a sample mean of 0.031 , and DEBT_ISSUANCE ranges from -0.232 to 0.618 with a sample mean of 0.021 .

To assess firm performance, we consider measures of both operating profitability and employment. EBIT equals the ratio of earnings before interest and taxes during a period to the book value of total assets at the start of the period. In robustness tests reported in Internet Appendix Table IA8, we use two additional profitability indicators. NET_INCOME equals the ratio of earnings after interest and taxes to the book value of total assets at the start of the period. We use NET_INCOME to account for variations in interest and tax expenses 
across countries. The other measure of profitability is CASH_FLOW, which equals the ratio of net earnings plus depreciation and amortization to the book value of assets at the start of the period. CASH_FLOW helps address concerns that differences in earnings management account for differences in the firm profitability measures. Finally, FIRM_EMPLOYMENT equals the natural logarithm of the total number of employees in a firm. Because Worldscope provides employment data in units of 1,000, FIRM_EMPLOYMENT equals 0 when a firm has 1,000 or fewer employees.

Table 1 shows that there is considerable variation in firm performance during banking crises. The values of EBIT range from -0.527 to 0.493 , with a sample mean of 0.057 and a standard deviation of 0.12 . The values of FIRM_EMPLOYMENT range from 0 to 13 with a standard deviation of 1.8 , suggesting that the number of workers in our sample of firms ranges from 1,000 to over 500,000 .

We use data on several other time-varying firm-level characteristics in our analyses, including firm size, long-term debt, and Tobin's Q. The definitions of these variables, which we discuss when we present the analyses later in the article, are provided in the Appendix. We winsorize all firm-level financial variables at the $1 \%$ and $99 \%$ levels to reduce the impact of outliers.

Figures 1 and 2 illustrate the changes in trade-credit financing, profits, and employment during banking crises. The figures suggest that TRADE CREDIT_FINANCING/COGS, EBIT, and FIRM_EMPLOYMENT drop less in countries with higher levels of TRUST. First, for each firm, we calculate the difference between i) the outcome variable averaged over the crisis period, $[t, t+3]$, and ii) the outcome variable averaged over the precrisis period, $[t-3, t-1]$, where $t$ denotes the start year of the country's banking crisis. Then we average the differences across all of the firms within the same country. Finally, we plot each country-level change against its precrisis level of trust. The fitted line in Figure 1 is upward-sloping, suggesting that although the amount of new trade credit that purchasers receive during banking crises falls in most countries (as the country averages for the change in TRADE_CREDIT_FINANCING/COGS are mostly below 0), it falls less in countries with higher levels of TRUST, which, as defined previously, is measured before the crisis. Similarly, Figure 2 exhibits an upward-sloping relationship between TRUST and firm performance over banking crises. In particular, firm profits and firm employment tend to fall less during banking crises in countries with higher TRUST.

\section{E. Industry-Level Liquidity Needs Measures}

In most of our analyses, we seek to differentiate industries by the degree to which technology shapes their reliance on external liquidity, such as trade credit. Industries that require large amounts of working capital to finance their operations for technological reasons, such as the length of the production process, the mode of production (batch vs. continuous), the importance of smoothing investments over long periods, and the structure of the adjustment costs associated with altering investment plans, tend to rely more heavily on the provision of external liquidity. As argued by Raddatz (2006), among the different components of 


\section{FIGURE 1}

\section{Trade-Credit Financing during a Banking Crisis: By Country}

In Figure 1, each marker represents the average change in the ratio of TRADE_CREDIT_FINANCING/COGS for firms in a country against the level of social trust in the country. Specifically, we first calculate for each firm the difference between TRADE_CREDIT_FINANCING/COGS during a crisis, $[t, t+3]$, and before the crisis, $[t-3, t-1]$. We then average this difference across all of the firms within each individual country and plot the averaged difference in a country against its level of social trust. Source: Worldscope.

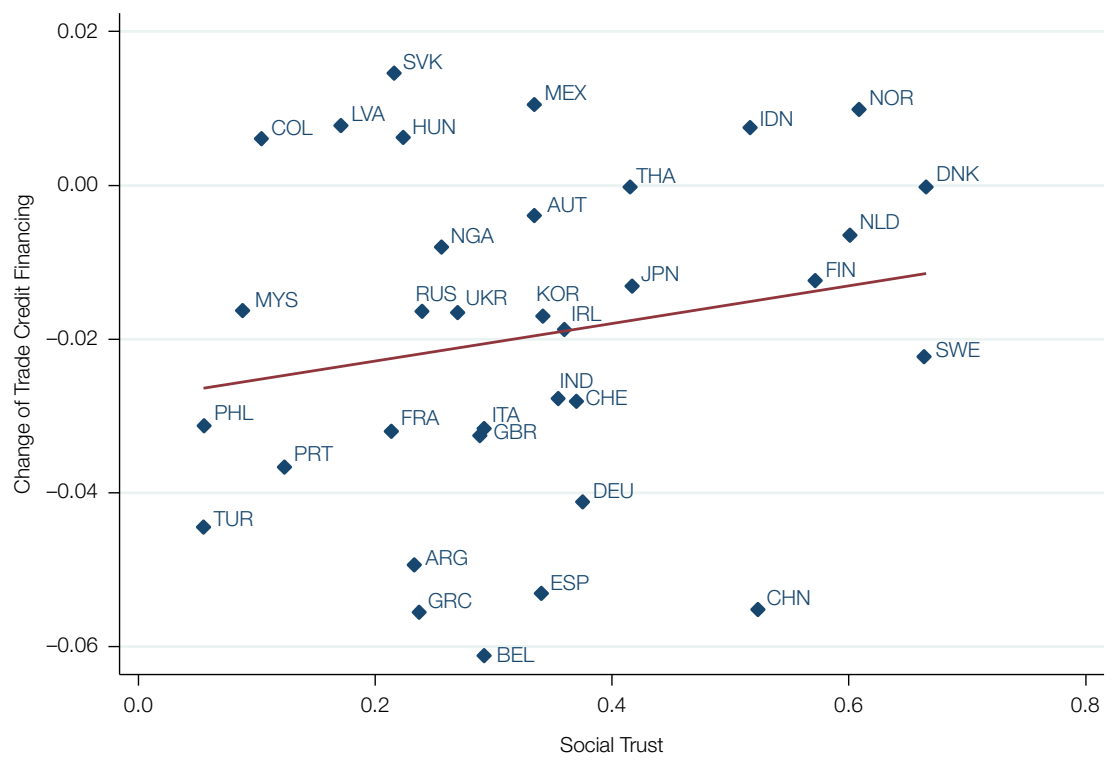

working capital, inventories are a particularly suitable proxy for the technological demand for liquid funds.

Thus, our proxy for an industry's technological reliance on trade credit, or more broadly, short-term liquidity, equals the ratio of inventories to sales and is calculated across U.S. companies at the 3-digit SIC industry level (LIQUIDITY_NEEDS). ${ }^{3}$ It measures the extent to which inventories cannot be financed by current revenue, such that higher values of LIQUIDITY_NEEDS indicate a greater reliance on external liquidity. In using data from the United States to create this proxy of the technological reliance of industries on external liquidity, we follow Rajan and Zingales (1998) in assuming that U.S. financial markets and institutions are relatively developed, and thus the crossindustry differences in the external liquidity needs of U.S. industries primarily reflect technological differences across industries in the demand for such funds. Furthermore, using one country to benchmark the technological liquidity needs of industries is advantageous because the liquidity needs of an industry may vary across countries due to differences in capital market development. We thus use

\footnotetext{
${ }^{3}$ We use Compustat to obtain the financial data of the U.S. companies, and we use the Center for Research in Security Prices (CRSP) to collect information on the U.S. SIC because CRSP provides time-varying data on the SIC of firms.
} 


\section{FIGURE 2}

\section{Firm Performance during a Banking Crisis: By Country}

In Figure 2, each marker represents the average change in the ratio of earnings before interest and taxes to total assets (EBIT) in Graph A, and the average change in the natural log of the number of employees (FIRM_EMPLOYMENT) in Graph B, for firms in a country against the level of social trust in the country. Specifically, we first calculate for each firm the difference between EBIT (FIRM EMPLOYMENT) during a crisis, [ $t, t+3]$, and before the crisis, [ $t-3, t-1]$. We then average this difference across all of the firms within each individual country and plot the averaged difference in a country against its level of social trust. Source: Worldscope.

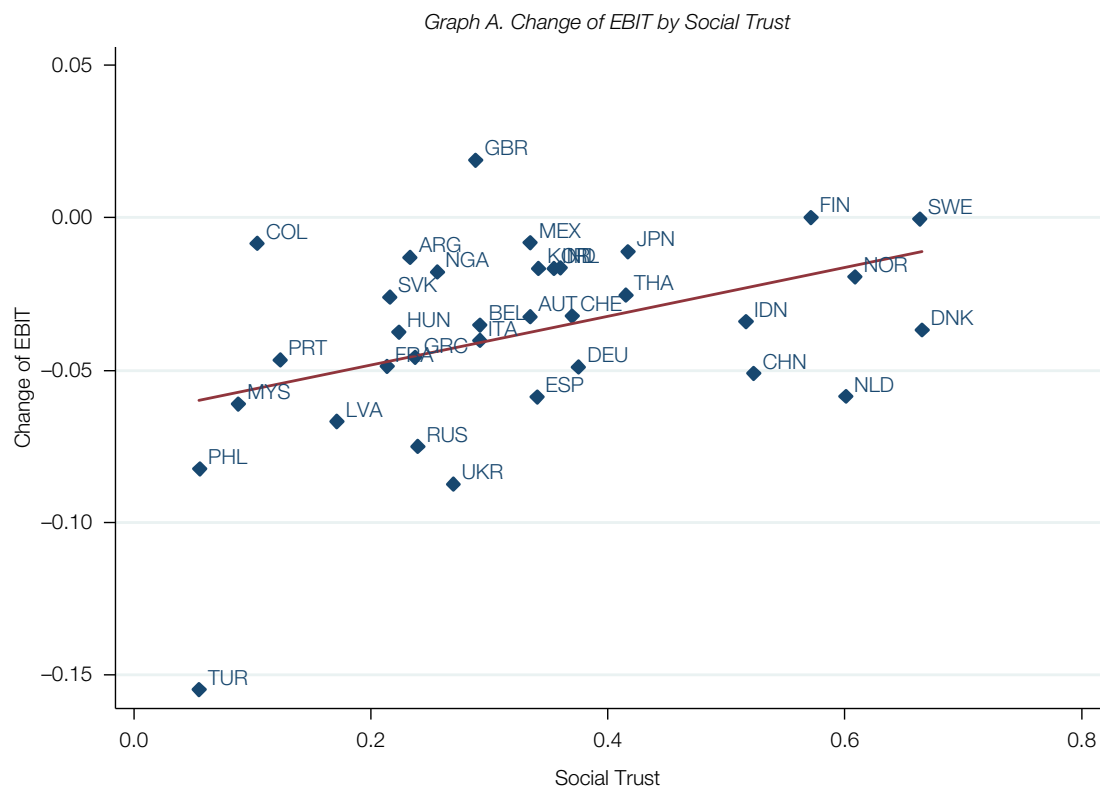

Graph B. Change of Employment by Social Trust

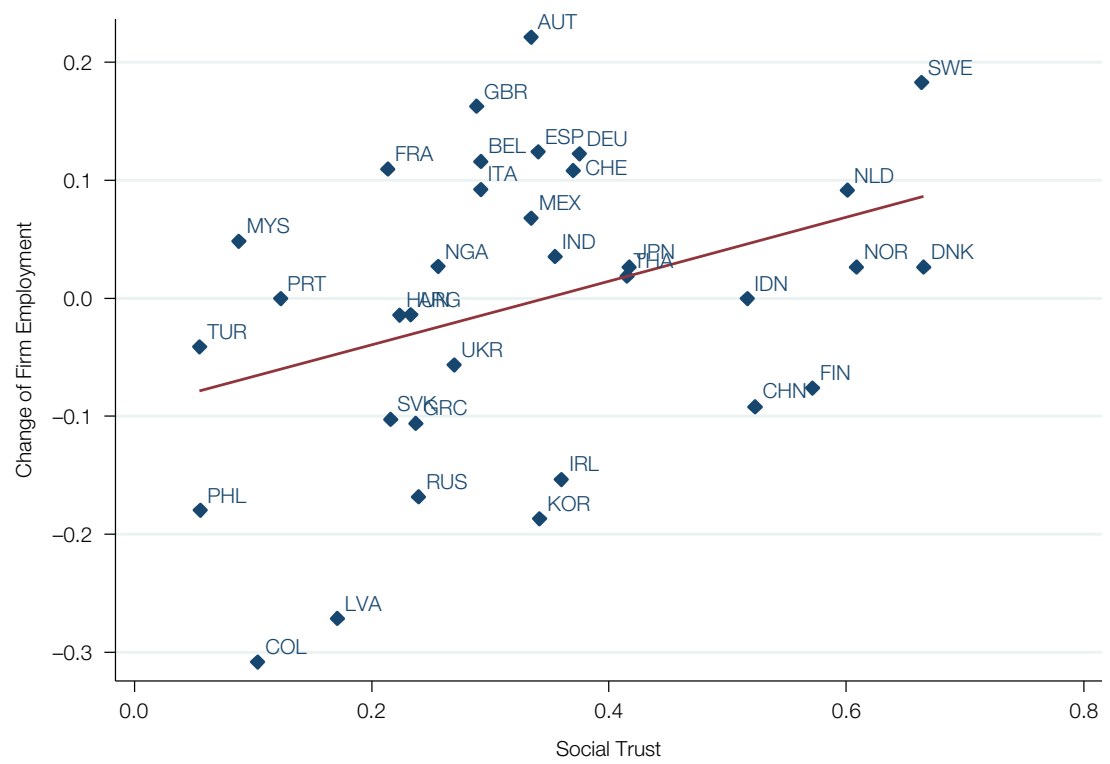


U.S. LIQUIDITY_NEEDS as a proxy for the technology-driven demand for trade credit across industries around the world.

For a country $c$ that experienced a crisis starting in year $t$, we construct its LIQUIDITY_NEEDS using U.S. industry data over the period from $t-10$ through $t-1$. For instance, given that a systemic banking crisis occurred in Japan in 1997, we use the U.S. data over the period of 1987-1996 to calculate LIQUIDITY_NEEDS for each industry in Japan. More specifically, for each U.S. firm $i$ within the 10-year window corresponding to crisis year $t$, we use Compustat to compute the ratio of inventories to sales in each year, and we then take the median value of this ratio over the 10-year window and call it $L_{i}$. Next, we calculate the median value of $L_{i}$ across U.S. firms with the same 3-digit SIC code and call this value the LIQUIDITY_NEEDS of that industry in crisis country $c$. Thus, LIQUIDITY_NEEDS i) is time-invariant for each crisis country and ii) differs across countries that experience systemic crises in different years.

In robustness tests reported in the Internet Appendix, we consider two alternative proxies for an industry's technological dependence on external liquidity. First, we examine INVENTORIES/COGS, which equals inventories divided by the cost of goods sold. Dividing inventories by the cost of sales, as opposed to the revenue of sales, is a common indicator of inventory turnover. A higher value of INVENTORIES/COGS suggests a lower speed of inventory turnover. With greater inventories and slower turnover, companies typically need more liquid funds for working capital. Second, we calculate for each industry the extent to which it uses trade credit. $\mathrm{Ng}$, Smith, and Smith (1999) show that trade credit tends to exhibit considerable variation across industries but little intertemporal variation within an industry, and Fisman and Love (2003) find a strong industry-specific element to accessing trade credit. Thus, we construct TRADE_CREDIT_RELIANCE as the ratio of ACCOUNT_PAYABLE to TOTAL_DEBT. We calculate both INVENTORIES/COGS and TRADE_CREDIT_RELIANCE for industries in the crisis countries using the same procedure as in the construction of LIQUIDITY_NEEDS. The Appendix provides detailed descriptions on how we construct these measures. We show that the results hold when using each of the three proxies for an industry's technological dependence on liquidity provision. We focus on LIQUIDITY_NEEDS because it is the most direct proxy for firms' dependence on liquid funds, as it is defined as the proportion of inventories (or working capital more broadly) that are financed by current sales.

Table 1 shows that there is considerable cross-industry variation in the three proxies for an industry's technological dependence on liquidity provision. The values of LIQUIDITY_NEEDS vary from 0.012 to 0.364 . This range is similar to that reported in Raddatz (2006), where the measure of liquidity needs is calculated using U.S. data over the 1980s. The other measure, INVENTORIES/COGS, exhibits a similar magnitude of variation. TRADE_CREDIT_RELIANCE has a minimum value of 0.055 and a maximum value of 2.717 . This means that the ratio of trade payable to total debt ranges from $5.5 \%$ to $271.7 \%$.

Figures 3 and 4 indicate that trade-credit financing, firm profits, and firm employment fall less during banking crises in high-trust countries than they fall in low-trust countries, and this difference is larger among industries with higher 


\section{FIGURE 3}

Change in Trade-Credit Financing by Industry Liquidity Needs

In Figure 3, each bar represents the average change in the ratio of trade-credit financing to total assets (TRADE_CREDIT_FINANCING/TOTAL_ASSETS). Specifically, we first calculate for each firm the difference between TRADE_CREDIT_FINANCING/TOTAL_ASSETS during a crisis, $[t, t+3]$, and before the crisis, $[t-3, t-1]$. We then average this difference across firms for four groups: high-liquidity-needs industries among high- versus low-trust countries and low-liquidity-needs industries among high-versus low-trust countries.

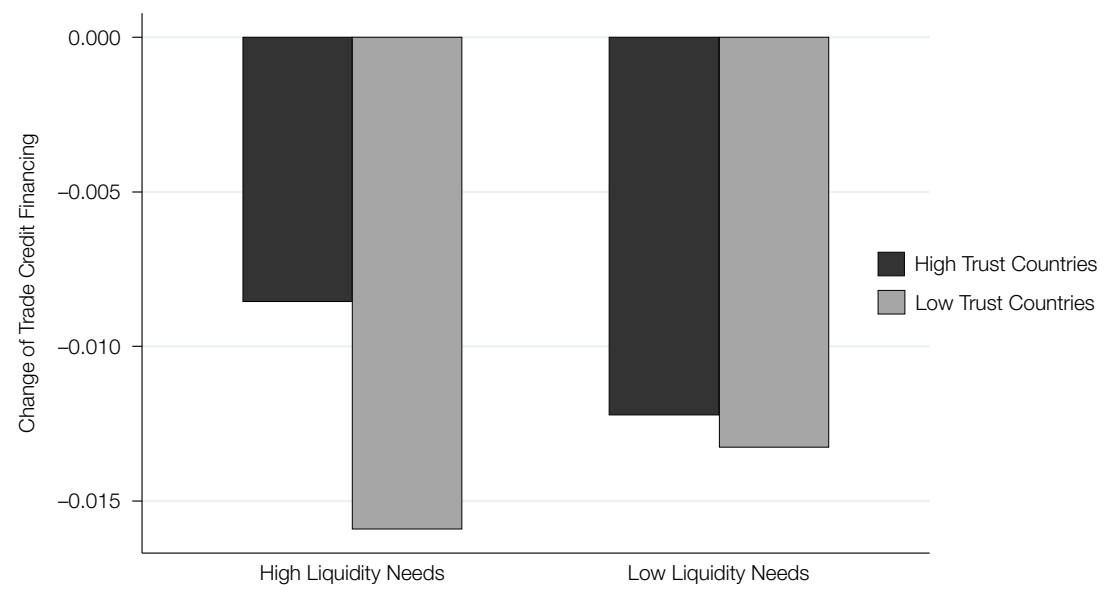

LIQUIDITY NEEDS. The figures plot the simple changes in firm outcome variables while differentiating between countries with high and low trust and between industries with high and low liquidity needs. For each firm, we calculate the difference between the outcome variables (trade-credit financing, earnings before interest and taxes, and employment, all scaled by the book value of total assets) averaged over the crisis period, $[t, t+3]$, and the corresponding precrisis period, $[t-3, t-1]$. We then average the differences across firms in four groups: high- (low-) liquidity-needs industries in countries with high trust, and high- (low-) liquidity-needs industries in countries with low trust. We classify a country into the high- (low-) trust group if its level of trust lies above (below) the median value of the sample countries. We classify an industry into the high- (low-) liquidity-needs group if its measure of LIQUIDITY_NEEDS lies above (below) the median of the sample of industries. Figure 3 shows that among high-liquidity-needs industries, TRADE_CREDIT_FINANCING drops, on average, by $0.85 \%$ of total assets during a banking crisis in high-trust countries and drops by $1.6 \%$ in low-trust countries. In contrast, the difference in the drop in TRADE_CREDIT_FINANCING/TOTAL_ASSETS between high- and low-trust countries is negligible when focusing on low-liquidity-needs industries. Figure 4 shows that the changes in firm profits and employment during crises exhibit similar patterns, suggesting that firm profits and employment among high-liquidityneeds industries drop less in high-trust countries.

\section{F. Country Controls}

In assessing the association between social trust and firm outcomes, we control for time-varying country characteristics, such as macroeconomic conditions, 
FIGURE 4

Change in EBIT and Employees by Industry Liquidity Needs

In Figure 4, each bar represents the average change in the ratio of earnings before interest and taxes to total assets in Graph A and the average change in the ratio of the total number of employees to total assets in Graph B. Specifically, we first calculate for each firm the difference between firm performance during a crisis, $[t, t+3]$, and before the crisis, $[t-3, t-1]$. We then average this difference across firms for four groups: high-liquidity-needs industries among highversus low-trust countries and low-liquidity-needs industries among high- versus low-trust countries.
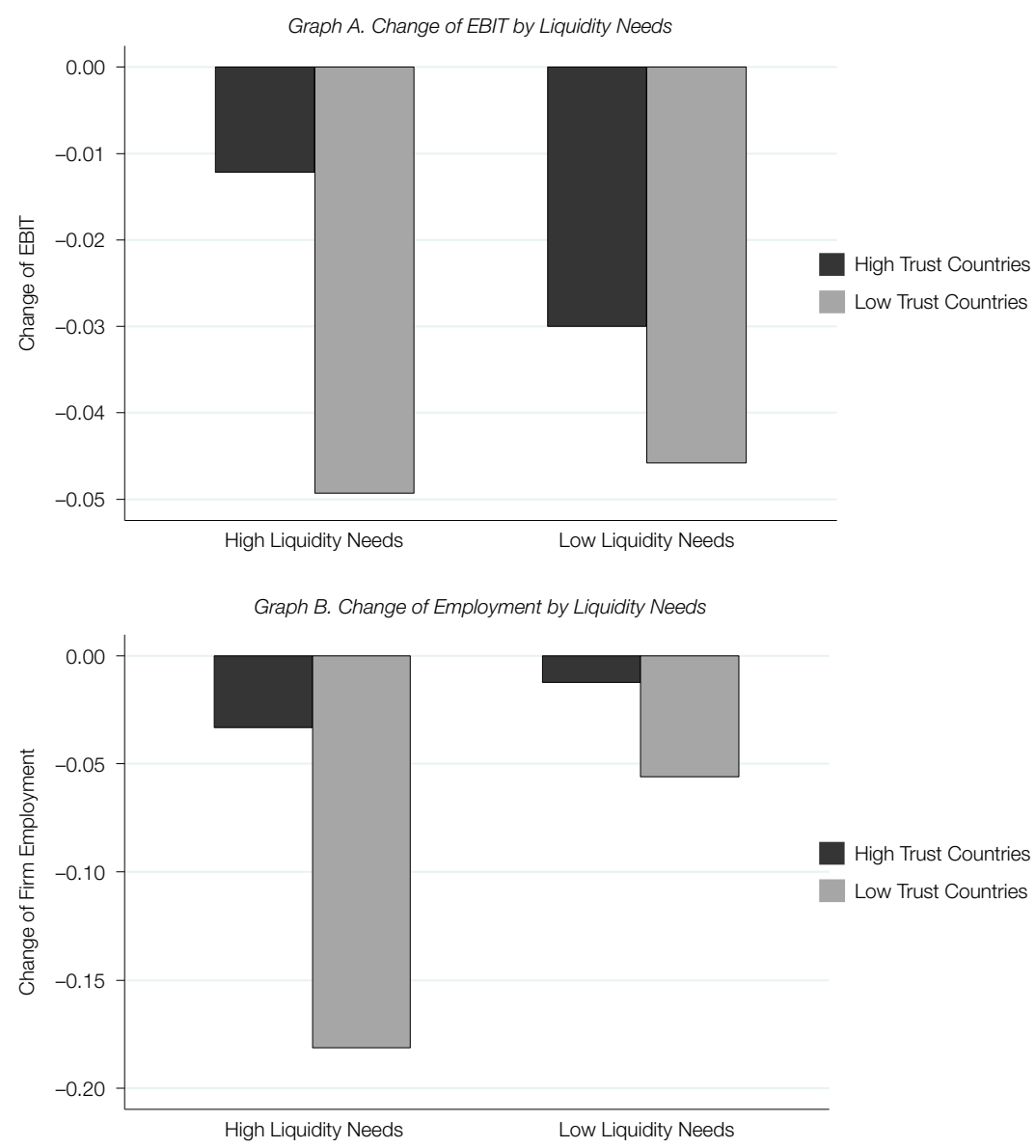

financial development, and investor protection laws, and call these macro controls. In the analyses, we interact each of these controls with CRISIS. First, to control for the possibility that firms in more developed economies perform relatively better during a crisis, we use GDP_PER_CAPITA, which equals the natural logarithm of GDP per capita measured 3 years before a country's crisis, $t-3$. Second, we use two variables to control for the development of financial intermediaries and markets. FINANCIAL_INSTITUTION_DEVELOPMENT equals private credit by banks and other financial institutions divided by GDP. STOCK_MARKET_DEVELOPMENT equals stock market capitalization divided by GDP. We use the values measured 3 years before the crisis. Third, we control 
for the size of a crisis by computing the contraction in the growth rate of credit. Specifically, PRIVATE_CREDIT_CONTRACTION equals the average annual growth rate of bank credit over the precrisis period, $[t-3, t-1]$, minus the minimum annual growth rate of bank credit over the crisis period, $[t, t+3]$, where $t$ is the start year of a banking crisis. By definition, larger PRIVATE_CREDIT_CONTRACTION means a greater reduction in bank credit growth and hence a more severe banking crisis. Fourth, we control for two types of investor protection laws because such laws might affect firm performance during a banking crisis. CREDITOR_RIGHTS is an index constructed by Djankov et al. (2007) based on bankruptcy and reorganization laws across countries. It measures the ability of creditors to voice their opinions, get repaid, and affect the process of reorganizing delinquent corporations. The overall index ranges from 0 to 4 , with higher values indicating greater creditor power. ANTI_SELF_DEALING is an index constructed by Djankov et al. (2008) to measure the extent to which minority shareholders are protected by the law from being expropriated by corporate insiders via self-dealing transactions. The index ranges from 0 to 1 , with larger values indicating that it is more difficult for large shareholders to engage in self-dealing transactions. The Appendix provides additional details on these macro controls, and Table 1 reports summary statistics. ${ }^{4}$

\section{Empirical Methodology}

To assess whether firms in countries with higher levels of social trust receive more financing and perform better during a banking crisis than similar firms in other countries, we begin with the following specification:

$$
\begin{gathered}
\text { FIRM_OUTCOME }_{i, c, t}=\alpha_{0}+\alpha_{i}+\alpha_{t}+\beta \times \text { TRUST }_{c} \times \text { CRISIS }_{c, t} \\
+\theta \times \text { CRISIS }_{c, t}+\varphi^{\prime} \times \text { MACRO }_{c} \times \text { CRISIS }_{c, t}+\gamma^{\prime} \times \text { FIRM }_{i, t-1}+\varepsilon_{i, c, t},
\end{gathered}
$$

where FIRM_OUTCOME $E_{i, c, t}$ refers to either trade credit received, equity issued, debt issued, profitability, or employment by firm $i$, in country $c$, during year $t ; \alpha_{i}$ and $\alpha_{t}$ are firm and year fixed effects; and $\mathrm{FIRM}_{i, t-1}$ represents a set of time-varying firm characteristics (e.g., FIRM_SIZE, LONG_TERM_DEBT, and TOBINS_Q). The variable of focus is TRUST $_{c} \times$ CRISIS $_{c, t}$, which is the interaction of the social trust measure for country $c$ and the systemic crisis dummy variable, CRISIS C $_{c, t}$. Recall that CRISIS C $_{c, t}$ equals 1 for country $c$ in years $t$ through $t+3$, and 0 otherwise, where $t$ is the start year of the systemic banking crisis. The estimated coefficient on the interaction between TRUST $_{c}$ and CRISIS $c, t, \beta$, measures the differential outcome during a crisis of firms operating in countries with different levels of social trust. The error term is denoted as $\varepsilon_{i, c, t}$. We employ ordinary least squares (OLS) to estimate the coefficients in equation (1). Heteroscedasticity robust standard errors are clustered at the country level. Our results hold when using 2-way clustering at the country and year levels, as shown in Internet Appendix Table IA3.

\footnotetext{
${ }^{4}$ In robustness tests, we control for additional country-level measures of the rule of law and institutional quality. We discuss these later in the article. The Appendix provides detailed variable definitions, and Table IA1 in the Internet Appendix lists these macro variables by each country.
} 
In equation (1), we control for several factors to better isolate the independent association between social trust and firm outcomes. We allow firm outcomes during crises to vary by i) the level of economic development, ii) the level of development of financial intermediaries, iii) the size of national stock exchanges, iv) the size of the banking crisis, v) the degree to which the legal system protects small investors from self-dealing by corporate insiders, and vi) the strength of the legal rights of creditors. Thus, equation (1) includes the interactions between CRISIS $_{c, t}$ and a vector of macro-country variables, which we call $\mathrm{MACRO}_{c}$, where $\mathrm{MACRO}_{c}$ includes GDP_PER_CAPITA, FINANCIAL_ INSTITUTION_DEVELOPMENT, STOCK_MARKET_DEVELOPMENT, PRIVATE_CREDIT_CONTRACTION, ANTI_SELF_DEALING, and CREDITOR_ RIGHTS. These macro-country variables, except PRIVATE_CREDIT CONTRACTION and ANTI_SELF_DEALING, are measured at $t-3$.

We then build on equation (1) to assess additional implications of the view that social trust increases corporate resilience to systemic banking crises. According to this view, social trust will exert a disproportionately positive impact on firms that, for technological reasons, rely comparatively heavily on liquid funds. To test this prediction, we first divide industries into those that depend heavily on liquidity for technological reasons and those that are less reliant on liquidity. We then evaluate whether firms in industries that depend heavily on liquidity perform comparatively better in countries with high levels of social trust during crises than similar firms in countries with lower levels of social trust and whether firms in liquidity-dependent industries perform comparatively better than other firms in the same country. As described previously in the data section, we distinguish industries by their natural degree of dependence on short-term liquidity (or trade credit) using three measures that all use the United States to benchmark industries. Specifically, we use i) LIQUIDITY_NEEDS, which equals the ratio of inventories to sales among U.S. firms in each industry; ii) INVENTORIES/COGS, which equals the ratio of inventories to cost of goods sold among U.S. firms in each industry; and iii) TRADE_CREDIT_RELIANCE, which equals the ratio of accounts payable to total debt among U.S. firms in each industry.

We address several challenges to identifying the impact of social trust on corporate resilience to systemic banking crises. First, we are concerned that social trust might be correlated with the size of banking crises. If this were the case, then our analyses might capture differences in the severity of crises, not the resilience of firms to crises of similar sizes. As reported in Internet Appendix Table IA2, however, there is not a statistically significant relation between banking crisis size (PRIVATE_CREDIT_CONTRACTION) and TRUST. Moreover, as noted previously, our analyses control for country fixed effects and the interaction between PRIVATE_CREDIT_CONTRACTION and CRISIS to condition out differences in the size of banking crises.

Second, to address the concern that our findings on corporate resilience to banking crises reflect other features of economies besides social trust, we do the following: In addition to controlling for firm and year fixed effects and an assortment of time-varying firm characteristics, we control for the interaction between social trust and measures of the size of the crisis, economic development, bank and stock market development, the degree to which the formal legal system 
protects creditors and shareholders, the effectiveness of the legal system in enforcing contracts, and the overall level of institutional development. Additionally, we augment these analyses and further differences by industry. We assess the differential response of high- and low-liquidity-needs industries to systemic crises in economies with different levels of social trust. In this way, we evaluate narrower, industry-specific predictions about the mechanisms through which social trust shapes corporate resilience to crises.

A third challenge to our identification strategy is pre-trends. We are concerned that there might be trends in corporate profits, employment, and trade credit that vary systematically across high- and low-trust countries and that even vary systematically across industries in high- and low-trust economies. To address this, we conduct three additional tests. First, we include COUNTRY_DUMMY ${ }_{c} \times$ TRENDS in equation (1), where COUNTRY $_{-}$ DUMMY $_{c}$ represents a vector of 34 country dummy variables, and TRENDS is a time-trend indicator that equals 1 in $t-3,2$ in $t-2, \ldots$, and 7 in $t+3$. Second, we include COUNTRY_INDUSTRY_DUMMY ${ }_{c, j} \times \mathrm{TRENDS}$ where COUNTRY_INDUSTRY_DUMMY ${ }_{c, j}$ represents a vector of 1,151 country-industry dummies at the 3-digit SIC level. These interaction terms account both for different trends across industries within the same country and for different trends between industries with the same SIC code across different countries. Third, we include FIRM_DUMMY ${ }_{i} \times$ TRENDS, where FIRM_DUMMY $_{i}$ is a set of 3,603 individual firm dummies. These additional terms remove differential trends across individual firms.

\section{Trust and Financing during Banking Crises}

Table 2 reports regression results evaluating whether social trust facilitates trade credit financing when an economy experiences a systemic banking crisis. We use two measures of trade credit. In columns 1-3, the dependent variable is changes in trade credit received relative to the cost of goods sold (TRADE_CREDIT_FINANCING/COGS), whereas the dependent variable in columns 4-6 is the ratio of changes in trade credit received to total assets (TRADE_CREDIT_FINANCING/TOTAL_ASSETS). For both measures of trade credit, Table 2 provides results on the full sample firms, on the subsample of firms with above the median value of LIQUIDITY_NEEDS (high LIQUIDITY_NEEDS), and on the subsample of firms with below the median value of LIQUIDITY_NEEDS (low LIQUIDITY_NEEDS). The variable of interest is the interaction term, TRUST $\times$ CRISIS, which captures the extent to which social trust facilitates trade credit when bank credit contracts during a crisis.

The results are consistent with the view that social trust improves firms' access to trade finance during systemic banking crises. Specifically, columns 2 and 5 of Table 2 show that i) the coefficient on TRUST $\times$ CRISIS is positive and statistically significant at the $1 \%$ level among firms in industries that rely heavily on trade credit for technological reasons (i.e., in industries with high LIQUIDITY_NEEDS), and ii) this positive association between social trust and trade-credit financing during crises holds when using either measure of trade credit (TRADE_CREDIT_FINANCING/COGS and 


\section{TABLE 2}

\section{Social Trust and Trade Credit over Banking Crises: $[t-3, t+3]$}

Table 2 reports regression results of the relation between social trust and firms' trade credit received during banking crises $[t-3, t+3]$, where $t$ is the start year of a systemic banking crisis defined in Laeven and Valencia (2013). The dependent variables are the net increase in trade-credit financing as a share of the cost of goods sold (TRADE_CREDIT_FINANCING/COGS) in columns 1-3 and the net increase in trade-credit financing as a share of total assets (TRADE_CREDIT_FINANCING/TOTAL_ASSETS) in columns 4-6. For each dependent variable, there are three columns corresponding to, in turn, overall sample, high-liquidity-needs industries, and low-liquidity-needs industries, where we partition industries by the median value of LIQUIDITY_NEEDS, which is defined as the ratio of inventories to total sales calculated at the 3-digit Standard Industrial Classification (SIC) level (Raddatz (2006)). CRISIS equals 1 in the start year of a crisis and for the 3 years afterward, $[t, t+3]$, and 0 otherwise, $[t-3, t-1]$. GDP_PER_CAPITA equals the natural logarithm of real gross domestic product (GDP) per capita, measured 3 years before the start year of the banking crisis. FINANCIAL_INSTITUTION_DEVELOPMENT equals the ratio of private credit by deposit money banks and other financial institutions to GDP, measured 3 years before the start year of the banking crisis. STOCK_MARKET_DEVELOPMENT equals the ratio of stock market capitalization to GDP, measured 3 years before the start year of the banking crisis. PRIVATE_CREDIT_CONTRACTION equals the average annual growth rate in bank credit to private firms between $t-3$ and $t-1$, where $t$ is the start year of the crisis, minus the minimum annual growth rate of bank credit to private firms during the period between $t$ and $t+3$. ANTI_SELF_DEALING is an index of the extent to which minority shareholders are protected by the laws from being expropriated by insiders through self-dealing transactions. CREDITOR_RIGHTS is an index of the laws providing creditors the legal ability to voice their opinions, get repaid, and affect the reorganization process. FIRM_SIZE (lag) equals the natural logarithm of total assets lagged by 1 year. LONG_TERM_DEBT (lag) equals long-term debt divided by total assets lagged by 1 year. TOBINS_Q (lag) equals the natural logarithm of [(market value of equity + book value of assets - book value of equity)/book value of assets] lagged by 1 year. Regression coefficients are estimated using ordinary least squares (OLS). $t$-statistics are reported in parentheses and calculated using robust standard errors clustered at the country level. ${ }^{* \star},{ }^{\star *}$, and ${ }^{*}$ indicate significance at the $1 \%, 5 \%$, and $10 \%$ levels, respectively.

\begin{tabular}{|c|c|c|c|c|c|c|}
\hline \multirow[b]{2}{*}{ Variable } & \multicolumn{3}{|c|}{$\begin{array}{l}\text { TRADE_CREDIT_ } \\
\text { FINANCING/COGS }\end{array}$} & \multicolumn{3}{|c|}{$\begin{array}{c}\text { TRADE_CREDIT_ } \\
\text { FINANCING/TOTAL_ASSETS }\end{array}$} \\
\hline & $\begin{array}{c}\text { All } \\
1\end{array}$ & $\begin{array}{c}\text { High } \\
\text { LIQUIDITY } \\
\text { NEEDS } \\
2\end{array}$ & $\begin{array}{c}\text { Low } \\
\text { LIQUIDITY_ } \\
\text { NEEDS } \\
3\end{array}$ & $\begin{array}{c}\text { All } \\
4\end{array}$ & $\begin{array}{c}\text { High } \\
\text { LIQUIDITY_ } \\
\text { NEEDS } \\
5\end{array}$ & $\begin{array}{c}\text { Low } \\
\text { LIQUIDITY } \\
\text { NEEDS } \\
6\end{array}$ \\
\hline TRUST $\times$ CRISIS & $\begin{array}{c}0.016 \\
(1.367)\end{array}$ & $\begin{array}{l}0.037^{\star * *} \\
(4.044)\end{array}$ & $\begin{array}{l}-0.009 \\
(-0.551)\end{array}$ & $\begin{array}{r}0.013^{*} \\
(2.024)\end{array}$ & $\begin{array}{l}0.027^{* * *} \\
(4.316)\end{array}$ & $\begin{array}{l}-0.003 \\
(-0.246)\end{array}$ \\
\hline CRISIS & $\begin{array}{l}-0.004 \\
(-0.166)\end{array}$ & $\begin{array}{l}-0.001 \\
(-0.054)\end{array}$ & $\begin{array}{l}-0.003 \\
(-0.115)\end{array}$ & $\begin{array}{c}0.002 \\
(0.081)\end{array}$ & $\begin{array}{l}-0.005 \\
(-0.286)\end{array}$ & $\begin{array}{c}0.009 \\
(0.353)\end{array}$ \\
\hline GDP_PER_CAPITA $\times$ CRISIS & $\begin{array}{l}-0.001 \\
(-0.579)\end{array}$ & $\begin{array}{l}-0.003 \\
(-1.543)\end{array}$ & $\begin{array}{l}-0.000 \\
(-0.149)\end{array}$ & $\begin{array}{l}-0.002 \\
(-0.764)\end{array}$ & $\begin{array}{l}-0.001 \\
(-0.365)\end{array}$ & $\begin{array}{l}-0.002 \\
(-1.000)\end{array}$ \\
\hline $\begin{array}{l}\text { FINANCIAL_INSTITUTION_ } \\
\text { DEVELOPMENT } \times \text { CRISIS }\end{array}$ & $\begin{array}{l}-0.007 \\
(-1.625)\end{array}$ & $\begin{array}{l}-0.012^{\star *} \\
(-2.619)\end{array}$ & $\begin{array}{l}-0.002 \\
(-0.288)\end{array}$ & $\begin{array}{l}-0.007^{\star \star *} \\
(-2.754)\end{array}$ & $\begin{array}{l}-0.014^{* \star *} \\
(-4.086)\end{array}$ & $\begin{array}{l}-0.000 \\
(-0.089)\end{array}$ \\
\hline $\begin{array}{l}\text { STOCK_MARKET } \\
\text { DEVELOPMENT } \times \text { CRISIS }\end{array}$ & $\begin{array}{l}0.007^{\star \star} \\
(2.207)\end{array}$ & $\begin{array}{l}0.009^{\star \star *} \\
(4.528)\end{array}$ & $\begin{array}{c}0.005 \\
(1.032)\end{array}$ & $\begin{array}{l}0.004^{\star \star} \\
(2.414)\end{array}$ & $\begin{array}{l}0.006^{* \star *} \\
(4.171)\end{array}$ & $\begin{array}{c}0.001 \\
(0.637)\end{array}$ \\
\hline $\begin{array}{l}\text { PRIVATE_CREDIT_ } \\
\text { CONTRACTION } \times \text { CRISIS }\end{array}$ & $\begin{array}{c}0.020 \\
(1.609)\end{array}$ & $\begin{array}{c}0.001 \\
(0.090)\end{array}$ & $\begin{array}{l}0.033^{\star \star} \\
(2.706)\end{array}$ & $\begin{array}{l}0.007 \\
(0.679)\end{array}$ & $\begin{array}{l}-0.005 \\
(-0.484)\end{array}$ & $\begin{array}{c}0.014 \\
(1.211)\end{array}$ \\
\hline ANTI_SELF_DEALING $\times$ CRISIS & $\begin{array}{l}-0.010 \\
(-1.058)\end{array}$ & $\begin{array}{c}0.004 \\
(0.425)\end{array}$ & $\begin{array}{l}-0.021^{\star} \\
(-1.897)\end{array}$ & $\begin{array}{l}-0.001 \\
(-0.268)\end{array}$ & $\begin{array}{c}0.008 \\
(1.376)\end{array}$ & $\begin{array}{l}-0.009 \\
(-1.623)\end{array}$ \\
\hline CREDITOR_RIGHTS $\times$ CRISIS & $\begin{array}{l}0.003^{\star \star} \\
(2.504)\end{array}$ & $\begin{array}{l}0.003^{* *} \\
(2.496)\end{array}$ & $\begin{array}{l}0.004^{\star \star} \\
(2.289)\end{array}$ & $\begin{array}{l}0.003^{\star \star \star} \\
(4.678)\end{array}$ & $\begin{array}{l}0.002^{\star \star *} \\
(3.638)\end{array}$ & $\begin{array}{l}0.003^{* * *} \\
(3.466)\end{array}$ \\
\hline FIRM_SIZE (lag) & $\begin{array}{l}-0.046^{\star \star \star} \\
(-11.890)\end{array}$ & $\begin{array}{l}-0.048^{\star \star \star} \\
(-9.215)\end{array}$ & $\begin{array}{l}-0.045^{\star \star \star} \\
(-10.650)\end{array}$ & $\begin{array}{l}-0.038^{\star \star \star} \\
(-13.490)\end{array}$ & $\begin{array}{l}-0.042^{* * *} \\
(-10.240)\end{array}$ & $\begin{array}{l}-0.036^{\star \star *} \\
(-11.390)\end{array}$ \\
\hline LONG_TERM_DEBT (lag) & $\begin{array}{r}0.025^{\star} \\
(1.883)\end{array}$ & $\begin{array}{c}0.009 \\
(0.469)\end{array}$ & $\begin{array}{l}0.038^{* *} \\
(2.726)\end{array}$ & $\begin{array}{l}0.019^{\star *} \\
(2.226)\end{array}$ & $\begin{array}{c}0.010 \\
(1.120)\end{array}$ & $\begin{array}{l}0.026^{\star *} \\
(2.730)\end{array}$ \\
\hline TOBINS_Q (lag) & $\begin{array}{l}0.013^{\star \star \star} \\
(2.792)\end{array}$ & $\begin{array}{l}0.013^{\star \star *} \\
(3.053)\end{array}$ & $\begin{array}{l}0.014^{\star *} \\
(2.121)\end{array}$ & $\begin{array}{l}0.008^{\star * *} \\
(3.737)\end{array}$ & $\begin{array}{l}0.010^{\star \star *} \\
(4.348)\end{array}$ & $\begin{array}{r}0.006^{*} \\
(1.815)\end{array}$ \\
\hline Constant & $\begin{array}{l}0.541^{* \star *} \\
(10.580)\end{array}$ & $\begin{array}{l}0.547^{\star \star \star} \\
(8.206)\end{array}$ & $\begin{array}{l}0.546^{\star \star \star} \\
(9.726)\end{array}$ & 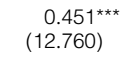 & $\begin{array}{l}0.502^{* * *} \\
(9.463)\end{array}$ & $\begin{array}{l}0.427^{\star \star \star} \\
(11.530)\end{array}$ \\
\hline $\begin{array}{l}\text { Firm fixed effects } \\
\text { Year fixed effects }\end{array}$ & $\begin{array}{l}\text { Yes } \\
\text { Yes }\end{array}$ & $\begin{array}{l}\text { Yes } \\
\text { Yes }\end{array}$ & $\begin{array}{l}\text { Yes } \\
\text { Yes }\end{array}$ & $\begin{array}{l}\text { Yes } \\
\text { Yes }\end{array}$ & $\begin{array}{l}\text { Yes } \\
\text { Yes }\end{array}$ & $\begin{array}{l}\text { Yes } \\
\text { Yes }\end{array}$ \\
\hline $\begin{array}{l}\text { No. of obs. } \\
\text { Country cluster } \\
\text { Adj. } R^{2}\end{array}$ & $\begin{array}{c}22,599 \\
34 \\
0.063\end{array}$ & $\begin{array}{c}11,296 \\
33 \\
0.078\end{array}$ & $\begin{array}{c}11,303 \\
34 \\
0.053\end{array}$ & $\begin{array}{c}22,775 \\
34 \\
0.090\end{array}$ & $\begin{array}{c}11,365 \\
33 \\
0.102\end{array}$ & $\begin{array}{c}11,410 \\
34 \\
0.084\end{array}$ \\
\hline $\begin{array}{l}F \text {-statistic }\left(\beta \_ \text {High }-\beta \_ \text {Low }=0\right) \\
\text { Prob. }>\chi^{2}\end{array}$ & & & & & & $22^{\star \star *}$ \\
\hline
\end{tabular}


TRADE_CREDIT_FINANCING/TOTAL_ASSETS). Furthermore, and consistent with theory, columns 3 and 6 show that TRUST $\times$ CRISIS enters insignificantly among firms in industries with low LIQUIDITY_NEEDS. Moreover, the difference in the coefficients on TRUST $\times$ CRISIS between the groups with high and low LIQUIDITY_NEEDS is statistically significant at least at the 5\% level, as shown at the bottom of the table.

The economic magnitudes are meaningful. To see this, consider a hypothetical "average" country with the sample average value of TRUST (0.328) and a hypothetical "high-trust" country with a value of TRUST that is 1 standard deviation higher than the average $(0.496=0.328+0.168)$. Furthermore, hold everything constant about these countries. The coefficient estimates reported in column 2 of Table 2 indicate that a banking crisis is associated with a reduction in trade-credit financing among firms with high LIQUIDITY_NEEDS of $1.4 \%$ of the firms' cost of goods sold for the average country and a reduction of only $0.8 \%$ among comparable firms in high-trust countries..$^{5}$ Thus, among firms in industries that depend heavily on liquid funds, those in the high-trust country experience a $43 \%(=(0.8-1.4) / 1.4)$ smaller contraction in trade credit than those in the average country during a systemic banking crisis. These results are robust to using the alternative measure of trade credit (TRADE_CREDIT_FINANCING/TOTAL_ASSETS). We find that both the statistical significance and the economic magnitudes of the estimated effects are very similar when using TRADE_CREDIT_FINANCING/TOTAL_ASSETS.

The results are robust to controlling for other factors. There might be concerns that the impact of a systemic crisis on the economy, including on the provision of trade credit, could reflect other features of the economy, such as the level of economic development, the size of financial institutions, the development of stock markets, and the degree to which the legal system protects creditors and small shareholders. Thus, the regressions control for the interaction between the CRISIS dummy and GDP_PER CAPITA, FINANCIAL_INSTITUTION_DEVELOPMENT, STOCK_MARKET_ DEVELOPMENT, CREDITOR_RIGHTS, and ANTI_SELF_DEALING. As shown in Table 2, the results hold when conditioning on these country characteristics. We are also concerned that social trust might influence the size of banking crises, which would confound our ability to assess the impact of social trust on trade credit. Thus, we also include the interaction between CRISIS and PRIVATE_CREDIT_CONTRACTION. Again, the results on the response of trade credit to a systemic crisis are robust to controlling for the contraction in bank

\footnotetext{
${ }^{5}$ We calculate this figure using the coefficient estimates from column 2 in Table 2 and the corresponding sample means in Table 1. For the high-liquidity-needs industries, the trade-credit financing received from suppliers falls by $1.4 \%$ of the COGS in the hypothetical "average" country $[-0.01435=(0.0369 \times 0.328)-0.0012-(0.00321 \times 9.211)-(0.0121 \times 0.807)+(0.00858 \times 0.579)$ $+(0.00111 \times 0.287)+(0.00448 \times 0.440)+(0.00331 \times 2.059)]$ and by $0.8 \%$ of the COGS in the "high-trust" country $[-0.008157=(0.0369 \times 0.496)-0.0012-(0.00321 \times 9.211)-(0.0121 \times$ $0.807)+(0.00858 \times 0.579)+(0.00111 \times 0.287)+(0.00448 \times 0.440)+(0.00331 \times 2.059)]$. Thus, firms in the high-trust country experience a $43 \%(=(1.4-0.8) / 1.4)$ smaller drop in trade-credit financing than those in the average country over a banking crisis.
} 
credit, further emphasizing the positive connection between trust and trade credit following systemic banking crises.

The results are also robust to using two alternative proxies for the liquidity dependence of industries. The first alternative proxy is INVENTORIES/COGS, which differs from LIQUIDITY_NEEDS in that it scales inventories by the cost of goods sold rather than by sales. The second alternative is TRADE_CREDIT_RELIANCE, which equals accounts payable divided by total debt. The analyses in Internet Appendix Table IA4 are similar to those in Table 2, except that Table IA4 partitions by high and low values of INVENTORIES/COGS in columns 1-2 and by high and low values of TRADE_CREDIT_RELIANCE in columns 3-4. As shown, we continue to find that firms in liquidity-dependent industries receive considerably more trade credit during banking crises in high-trust countries than comparable firms in low-trust countries. That is, TRUST $\times$ CRISIS enters positively and significantly among liquidity-dependent firms but insignificantly among firms that depend less on external liquidity for their operations. These results are consistent with the view that social trust facilitates the provision of trade credit when there is a contraction in bank credit during systemic crises.

We are concerned that TRUST might be correlated with the quality of formal legal, regulatory, and political institutions, which might confound our ability to identify the impact of social trust on corporate resilience. To address this concern, we control for the interaction between CRISIS and the RULE_OF_LAW and INSTITUTIONAL_QUALITY in Table 3. RULE_OF_LAW measures the extent to which agents have confidence in and abide by the rules of society, particularly the enforcement quality of private and official contracts. INSTITUTIONAL_QUALITY is an index that aggregates information on i) the legal protection of private property, ii) the freedom of speech and accountability of government officials, iii) political stability, iv) government effectiveness, v) the ability of the government to implement regulatory policies, vi) the RULE_OF_LAW, and vii) the extent to which institutions control corruption. Similar to Table 2, Table 3 splits the sample based on the median value of industrial LIQUIDITY_NEEDS.

Table 3 shows that after controlling for the quality of formal institutions, all of the results hold. The coefficients on TRUST $\times$ CRISIS in the industry group with high LIQUIDITY_NEEDS remain statistically significant and economically meaningful after controlling for these additional interactions, whereas those in the industry group with low LIQUIDITY_NEEDS remain insignificant. Moreover, the estimated coefficients for the industry group with high LIQUIDITY_NEEDS do not fall when controlling for institutional quality. These results are consistent with our conjecture that it is the mutual trust between firms, not the rule of law or the quality of institutions, that plays a significant role in facilitating trade credit as a substitute to bank credit during a crisis. ${ }^{6}$

We are also concerned that i) firms in high-trust countries might have different time trends in trade credit from those in low-trust countries, ii) firms in

\footnotetext{
${ }^{6}$ As shown in Table IA5 of the Internet Appendix, all of these results hold when using the two alternative metrics for differentiating between high- and low-liquidity-needs industries: INVENTORIES/COGS and TRADE_CREDIT_RELIANCE.
} 
TABLE 3

Social Trust and Trade Credit: Additional Controls

Table 3 reports regression results of the relation between social trust and firms' trade credit received during banking crisis episodes while controlling for measures of legal and institutional development. The dependent variables are the net increase in trade-credit financing as a share the cost of goods sold (TRADE_CREDIT_FINANCING/COGS) in columns 1-4 and the net increase in trade-credit financing as a share of total assets (TRADE_CREDIT_FINANCING/TOTAL_ASSETS) in columns 5-8. For each dependent variable, results are provided for both high- and low-liquidity-needs industries, where we partition industries by the median value of LIQUIDITY_NEEDS, which equals the ratio of inventories to total sales calculated at the 3-digit Standard Industrial Classification (SIC) level (Raddatz (2006)). CRISIS equals 1 in the start year of a crisis and for the 3 years afterward, $[t, t+3]$, and 0 otherwise, $[t-3, t-1]$. Columns $1-2$ and 5-6 control for the interaction between CRISIS and the RULE_OF_LAW, which measures the quality of contract enforcement, property rights, and control over crime and violence. Columns 3-4 and 7-8 control for the interaction between CRISIS and INSTITUTIONAL_QUALITY, which is a broad index of institutional quality, including property rights, voice of accountability, political stability and absence of violence, government effectiveness, regulatory quality, rule of law, and control of corruption. The macroeconomic interaction controls include CRISIS interacted with the following: GDP_PER_CAPITA, FINANCIAL_INSTITUTION_DEVELOPMENT, STOCK_MARKET_DEVELOPMENT, PRIVATE_CREDIT_CONTRACTION, ANTISSELF_DEALING, and CREDITOR RIGHTS. The firm controls include the following: FIRM_SIZE (lag), LONG_TERM_DEBT (lag), and TOBINS_Q (lag). Variable definitions are provided in the Appendix. Regression coefficients are estimated using ordinary least squares (OLS). $t$-statistics are reported in parentheses and calculated using robust standard errors clustered at the country level. ${ }^{* * *}$, ${ }^{*}$, and ${ }^{*}$ indicate significance at the $1 \%, 5 \%$, and $10 \%$ levels, respectively.

\begin{tabular}{|c|c|c|c|c|c|c|c|c|}
\hline & \multicolumn{4}{|c|}{$\begin{array}{l}\text { TRADE_CREDIT_- } \\
\text { FINANCING/COGS }\end{array}$} & \multicolumn{4}{|c|}{$\begin{array}{c}\text { TRADE_CREDIT- } \\
\text { FINANCING/TOTAL_ASSSETS }\end{array}$} \\
\hline & \multicolumn{8}{|c|}{ Liquidity Needs } \\
\hline & High & Low & High & Low & High & Low & High & Low \\
\hline Variable & 1 & 2 & 3 & 4 & 5 & 6 & 7 & 8 \\
\hline TRUST $\times$ CRISIS & $\begin{array}{l}0.038^{\star \star \star} \\
(4.113)\end{array}$ & $\begin{array}{l}-0.008 \\
(-0.493)\end{array}$ & $\begin{array}{l}0.036^{\star \star \star} \\
(3.979)\end{array}$ & $\begin{array}{l}-0.012 \\
(-0.760)\end{array}$ & $\begin{array}{l}0.032^{\star \star \star} \\
(4.780)\end{array}$ & $\begin{array}{l}-0.000 \\
(-0.021)\end{array}$ & $\begin{array}{l}0.031^{\star \star \star} \\
(4.602)\end{array}$ & $\begin{array}{l}-0.003 \\
(-0.229)\end{array}$ \\
\hline CRISIS & $\begin{array}{l}-0.005 \\
(-0.219)\end{array}$ & $\begin{array}{l}-0.005 \\
(-0.149)\end{array}$ & $\begin{array}{c}0.002 \\
(0.098)\end{array}$ & $\begin{array}{c}0.011 \\
(0.275)\end{array}$ & $\begin{array}{l}-0.019 \\
(-0.952)\end{array}$ & $\begin{array}{l}0.001 \\
(0.053)\end{array}$ & $\begin{array}{l}-0.017 \\
(-0.728)\end{array}$ & $\begin{array}{r}0.008 \\
(0.271)\end{array}$ \\
\hline $\begin{array}{l}\text { RULE_OF } \\
\qquad \text { LAW } \times \text { CRISIS }\end{array}$ & $\begin{array}{l}-0.001 \\
(-0.313)\end{array}$ & $\begin{array}{l}-0.001 \\
(-0.125)\end{array}$ & & & $\begin{array}{l}-0.005 \\
(-1.149)\end{array}$ & $\begin{array}{c}-0.003 \\
(-0.911)\end{array}$ & & \\
\hline $\begin{array}{l}\text { INSTITUTIONAL } \\
\text { QUALITY } \times \text { CRISIS }\end{array}$ & & & $\begin{array}{c}0.000 \\
(0.185)\end{array}$ & $\begin{array}{c}0.002 \\
(0.472)\end{array}$ & & & $\begin{array}{l}-0.001 \\
(-0.592)\end{array}$ & $\begin{array}{l}-0.000 \\
(-0.037)\end{array}$ \\
\hline $\begin{array}{l}\text { Macroeconomic } \\
\text { interaction controls }\end{array}$ & Yes & Yes & Yes & Yes & Yes & Yes & Yes & Yes \\
\hline Firm controls & Yes & Yes & Yes & Yes & Yes & Yes & Yes & Yes \\
\hline Firm fixed effects & Yes & Yes & Yes & Yes & Yes & Yes & Yes & Yes \\
\hline Year fixed effects & Yes & Yes & Yes & Yes & Yes & Yes & Yes & Yes \\
\hline $\begin{array}{l}\text { No. of obs. } \\
\text { Country cluster }\end{array}$ & $\begin{array}{c}11,296 \\
33\end{array}$ & $\begin{array}{c}11,303 \\
34\end{array}$ & $\begin{array}{c}11,296 \\
33\end{array}$ & $\begin{array}{c}11,303 \\
34\end{array}$ & $\begin{array}{c}11,365 \\
33\end{array}$ & $\begin{array}{c}11,410 \\
34\end{array}$ & $\begin{array}{c}11,365 \\
33\end{array}$ & $\begin{array}{c}11,410 \\
34\end{array}$ \\
\hline Adj. $R^{2}$ & 0.078 & 0.053 & 0.078 & 0.053 & 0.102 & 0.084 & 0.102 & 0.084 \\
\hline $\begin{array}{l}F \text {-statistic } \\
\quad\left(\beta \_ \text {High }-\beta \_ \text {Low }=0\right)\end{array}$ & \multicolumn{2}{|c|}{$10.87^{\star \star \star}$} & \multicolumn{2}{|c|}{$12.44^{\star \star \star}$} & \multicolumn{2}{|c|}{$5.92^{\star \star}$} & \multicolumn{2}{|c|}{$6.30^{\star \star}$} \\
\hline Prob. $>\chi^{2}$ & \multicolumn{2}{|c|}{$(0.001)$} & \multicolumn{2}{|c|}{$(0.000)$} & \multicolumn{2}{|c|}{$(0.015)$} & \multicolumn{2}{|c|}{$(0.012)$} \\
\hline
\end{tabular}

high-liquidity-dependent industries might have different trends in trade credit from those in low-liquidity-dependent industries in the same country, and iii) firms in high- (and low-) liquidity-dependent industries in high-trust countries might have different trends in this alternative financing from corresponding firms in lowtrust countries. To address these concerns, we include TRENDS interacted with i) 34 country dummies, ii) 1,151 country-industry dummies, or iii) 3,603 individual firm dummies. By adding these additional trend controls, we explicitly account for the preexisting time trends across countries, country-industries, and firms.

As shown in Table 4, the results hold when accounting for these different trends. Columns1, 4, and 7 indicate that TRUST $\times$ CRISIS enters positively and statistically in the trade-credit financing regression after controlling for individual country, country-industry, or firm trends, respectively, and while continuing to control for firm and year fixed effects as well as the time-varying macro-interaction and firm controls. Moreover, when we partition the overall sample into high- and low-liquidity-needs industries and 
control for individual country/country-industry/firm trends, the results indicate that the resilience-enhancing effects of social trust on trade credit are more profound among industries that depend heavily on short-term liquidity. These results are fully consistent with the main findings in Table 2. Although Table 4 uses TRADE_CREDIT_FINANCING/COGS as the dependent variable throughout the columns, all the results hold when using the other measure, TRADE_CREDIT_FINANCING/TOTAL_ASSETS.

We are also concerned that the results might be distorted by trade credit provided by foreign suppliers. International trade credit would reflect trust across countries, rather than trust within the crisis country. To address this concern, we construct two subsamples of firms that are unlikely to receive trade credit from foreign suppliers during banking crises and then redo the analyses. Specifically, we form one subsample that only includes firms that have no reported foreign assets and a second subsample that only includes firms that have no documented foreign suppliers in recent years. For data on whether firms have foreign assets, we use the Worldscope database. To compile data on whether firms have

TABLE 4

Social Trust and Trade Credit over Banking Crises: Controlling for Time Trends

Table 4 reports regression results of the relation between social trust and firms' newly obtained trade credit during banking crises while controlling for different trends within country, country-industry, and individual firms. The dependent variables are the net increase in trade-credit financing as a share the cost of goods sold (TRADE_CREDIT_FINANCING/COGS) throughout the columns. For each set of time trends, there are three columns corresponding to the overall sample, high-liquidity-needs industries, and low-liquidity-needs industries, where we partition industries by the median value of LIQUIDITY NEEDS, which equals the ratio of inventories to total sales calculated at the 3-digit Standard Industrial Classification (SIC) level (Raddatz, (2006)). CRISIS equals 1 in the start year of a crisis and for the 3 years afterward, $[t, t+3]$, and 0 otherwise, $[t-3, t-1]$. Columns $1-3$ control for the interaction between COUNTRY DUMMY and the time-trend variable, TRENDS, indicating one of the years over $[t-3, t+3]$. In particular, TRENDS is set to 1 for $t-3,2$ for $t-2,3$ for $t-3,4$ for $t, 5$ for $t+1,6$ for $t+2$, and 7 for $t+3$. Columns $4-6$ control for the interaction between COUNTRY_INDUSTRY_DUMMY (at the 3-digit SIC level) and TRENDS. Columns 7-9 control for the interaction between FIRM_DUMMY and TRENDS. The macroeconomic interaction controls include CRISIS interacted with the following: GDP_PER_CAPITA, FINANCIAL_INSTITUTION_DEVELOPMENT, STOCK_MARKET_DEVELOPMENT, PRIVATE_CREDIT_CONTRACTION, ANTI_SELF_DEALING, and CREDITOR_RIGHTS. The firm controls include the following: FIRM_SIZE (lag), LONG_TERM_DEBT (lag), and TOBINS_Q (lag). Variable definitions are provided in the Appendix. Regression coefficients are estimated using ordinary least squares (OLS). $t$-statistics are reported in parentheses and calculated using robust standard errors clustered at the country level. ${ }^{* * *},{ }^{* *}$, and ${ }^{*}$ indicate significance at the $1 \%, 5 \%$, and $10 \%$ levels, respectively.

\begin{tabular}{|c|c|c|c|c|c|c|c|c|c|}
\hline & \multicolumn{9}{|c|}{ TRADE_CREDIT_FINANCING/COGS } \\
\hline & All & $\begin{array}{c}\text { High } \\
\text { LIQUIDITY } \\
\text { NEEDS }\end{array}$ & $\begin{array}{l}\text { Low } \\
\text { LIQUIDITY } \\
\text { NEEDS }\end{array}$ & All & $\begin{array}{c}\text { High } \\
\text { LIQUIDITY_ } \\
\text { NEEDS }\end{array}$ & $\begin{array}{l}\text { Low } \\
\text { LIQUIDITY } \\
\text { NEEDS }\end{array}$ & All & $\begin{array}{c}\text { High } \\
\text { LIQUIDITY } \\
\text { NEEDS }\end{array}$ & $\begin{array}{l}\text { Low } \\
\text { LIQUIDITY } \\
\text { NEEDS }\end{array}$ \\
\hline Variable & 1 & 2 & 3 & 4 & 5 & 6 & 7 & 8 & 9 \\
\hline TRUST $\times$ CRISIS & $\begin{array}{l}0.072^{\star \star \star} \\
(2.894)\end{array}$ & $\begin{array}{l}0.102^{\star \star \star} \\
(4.572)\end{array}$ & $\begin{array}{c}0.034 \\
(1.022)\end{array}$ & $\begin{array}{c}0.069^{\star \star} \\
(2.666)\end{array}$ & $\begin{array}{l}0.102^{\star \star \star} \\
(4.336)\end{array}$ & $\begin{array}{c}0.027 \\
(0.803)\end{array}$ & $\begin{array}{c}0.066^{\star \star} \\
(2.343)\end{array}$ & $\begin{array}{l}0.108^{\star \star \star} \\
(4.067)\end{array}$ & $\begin{array}{c}0.016 \\
(0.464)\end{array}$ \\
\hline CRISIS & $\begin{array}{c}0.036 \\
(0.755)\end{array}$ & $\begin{array}{c}0.018 \\
(0.412)\end{array}$ & $\begin{array}{c}0.068 \\
(1.051)\end{array}$ & $\begin{array}{c}0.039 \\
(0.751)\end{array}$ & $\begin{array}{c}0.023 \\
(0.499)\end{array}$ & $\begin{array}{c}0.073 \\
(1.049)\end{array}$ & $\begin{array}{c}0.049 \\
(0.774)\end{array}$ & $\begin{array}{c}0.046 \\
(0.832)\end{array}$ & $\begin{array}{c}0.078 \\
(0.955)\end{array}$ \\
\hline $\begin{array}{l}\text { Macroeconomic } \\
\text { interaction controls }\end{array}$ & Yes & Yes & Yes & Yes & Yes & Yes & Yes & Yes & Yes \\
\hline Firm controls & Yes & Yes & Yes & Yes & Yes & Yes & Yes & Yes & Yes \\
\hline Firm fixed effects & Yes & Yes & Yes & Yes & Yes & Yes & Yes & Yes & Yes \\
\hline Year fixed effects & Yes & Yes & Yes & Yes & Yes & Yes & Yes & Yes & Yes \\
\hline $\begin{array}{l}\text { COUNTRY_DUMMY } \\
\times \text { TRENDS }\end{array}$ & Yes & Yes & Yes & & & & & & \\
\hline $\begin{array}{l}\text { COUNTRY_INDUSTRY } \\
\text { DUMMY } \times \text { TRENDS }\end{array}$ & & & & Yes & Yes & Yes & & & \\
\hline FIRM_DUMMY $\times$ TRENDS & & & & & & & Yes & Yes & Yes \\
\hline $\begin{array}{l}\text { No. of obs. } \\
\text { Country cluster }\end{array}$ & $\begin{array}{c}22,599 \\
34\end{array}$ & $\begin{array}{c}11,296 \\
33\end{array}$ & $\begin{array}{c}11,303 \\
34\end{array}$ & $\begin{array}{c}22,599 \\
34\end{array}$ & $\begin{array}{c}11,296 \\
33\end{array}$ & $\begin{array}{c}11,303 \\
34\end{array}$ & $\begin{array}{c}22,599 \\
34\end{array}$ & $\begin{array}{c}11,296 \\
33\end{array}$ & $\begin{array}{c}11,303 \\
34\end{array}$ \\
\hline Adj. $R^{2}$ & 0.069 & 0.084 & 0.059 & 0.085 & 0.091 & 0.083 & 0.115 & 0.102 & 0.133 \\
\hline $\begin{array}{l}F \text {-statistic } \\
\quad\left(\beta \_ \text {High }-\beta \text { Low }=0\right)\end{array}$ & & & 0 0* & & & $4^{\star \star \star}$ & & 12.5 & $56^{\star \star \star}$ \\
\hline Prob. $>\chi^{2}$ & & $(0.0$ & 18) & & & 04) & & & Do0) \\
\hline
\end{tabular}


supply-chain relations with foreign supplies, we use the Revere database, which provides supply-chain information on publicly listed firms. The Revere data uncover business relationships for more than 21,000 companies globally with over 300,000 supply-chain relations. Because the data start in 2003, we use each firm's supply-chain relations since 2003 to infer whether a firm has any foreign suppliers. As shown in Internet Appendix Table IA6, the results hold when examining these two subsamples of firms. Although the sample sizes fall by approximately $20 \%-40 \%$, the coefficient estimates on TRUST $\times$ CRISIS remain economically and statistically robust, and the estimated coefficients on TRUST $\times$ CRISIS are similar in magnitude to those reported in Tables 2 and 3. These results reduce concerns that the results are influenced by the provision of foreign trade credit.

We next explore whether greater social trust is also associated with corporations issuing more equity and debt during banking crises. As discussed in the Introduction, several existing studies suggest that social trust exerts a larger impact on informal transactions, such as the extension of trade credit, than it does on more formal financing channels, such as equity and debt issuance. From this perspective, trust will primarily affect corporate resilience through the trade-credit channel rather than by influencing equity and debt issuance that relies on formal legal arrangements.

The results reported in Table 5 indicate that TRUST does not affect a firm's issuance of equity and debt during banking crises. As shown, TRUST $\times$ CRISIS enters insignificantly in both the EQUITY_ISSUANCE and DEBT_ISSUANCE regressions, whether examining the full sample or when splitting the sample into industries with high and low LIQUIDITY_NEEDS. The results suggest that social trust does not affect corporate resilience by shaping a firm's access to equity and debt.

We further explore whether a firm's access to equity and debt markets affects the connection between trust and trade credit during banking crises. For each firm, we construct two measures of a firm's access to equity and debt during crises. First, we calculate ACCESSIBILITY_TO_ EQUITY_AND_DEBT, which equals the average issuance of equity and debt (EQUITY_ISSUANCE + DEBT_ISSUANCE) during crisis periods, $[t, t+3]$, minus the average issuance of equity and debt (EQUITY ISSUANCE + DEBT_ISSUANCE) before the crisis, $[t-3, t-1]$. Second, we calculate ACCESSIBILITY_TO_EQUITY_AND_DEBT (dummy), which equals 1 if ACCESSIBILITY_TO_EQUITY_AND_DEBT is greater than the sample median, and 0 otherwise. We then redo the analyses while adding two additional interactions terms. When using the ACCESSIBILITY TO_EQUITY_AND_DEBT measure, we include both the triple-interaction term, TRUST $\times$ CRISIS $\times$ ACCESSIBILITY_TO_EQUITY_AND_DEBT, and ACCESSIBILITY_TO_EQUITY_AND_DEBT $\times$ CRISIS in the baseline specification. We use an analogous specification when examining ACCESSIBILITY_ TO_EQUITY_AND_DEBT (dummy). As shown in Internet Appendix Table IA7, all of the earlier results are robust to including these additional interaction terms to control for the firms' access to equity and debt markets. 
Table 5 reports regression results of the relation between social trust and firms' issuances of equity and debt during banking crises. The dependent variables are EQUITY_ISSUANCE in columns 1-3 and DEBT_ISSUANCE in columns 4-6. For each dependent variable, there are three columns corresponding, respectively, to overall sample, high-liquidity-needs industries, and low-liquidity-needs industries, where we partition industries by the median value of LIQUIDITY_NEEDS. CRISIS equals 1 in the start year of a crisis and for the 3 years afterward, $[t, t+3]$, and 0 otherwise, $[t-3, t-1]$. The macroeconomic interaction controls include CRISIS interacted with the following: GDP_PER_CAPITA, FINANCIAL_INSTITUTION_DEVELOPMENT, STOCK_MARKET_DEVELOPMENT, PRIVATE_CREDIT_CONTRACTION, ANTI_SELF_DEALING, and CREDITOR_RIGHTS. The firm controls include the following: FIRM_SIZE (lag), LONG_TERM_DEBT (lag), TOBINS_Q (lag), and CASH_FLOW. Variable definitions are provided in the Appendix. Regression coefficients are estimated using ordinary least squares (OLS). $t$-statistics are reported in parentheses and calculated using robust standard errors clustered at the country level. ${ }^{\star \star \star},{ }^{\star \star}$, and ${ }^{*}$ indicate significance at the $1 \%, 5 \%$, and $10 \%$ levels, respectively.

\begin{tabular}{|c|c|c|c|c|c|c|}
\hline \multirow{3}{*}{ Variable } & \multicolumn{3}{|c|}{ EQUITY_ISSUANCE } & \multicolumn{3}{|c|}{ DEBT_ISSUANCE } \\
\hline & All & $\begin{array}{l}\text { High } \\
\text { LIQUIDITY_- } \\
\text { NEEDS }\end{array}$ & $\begin{array}{l}\text { Low } \\
\text { LIQUIDITY } \\
\text { NEEDS }\end{array}$ & All & $\begin{array}{l}\text { High } \\
\text { LIQUIDITY } \\
\text { NEEDS }\end{array}$ & $\begin{array}{l}\text { LOW } \\
\text { LIQUIDITY } \\
\text { NEEDS }\end{array}$ \\
\hline & 1 & 2 & 3 & 4 & 5 & 6 \\
\hline TRUST $\times$ CRISIS & $\begin{array}{c}0.034 \\
(1.037)\end{array}$ & $\begin{array}{c}0.046 \\
(1.279)\end{array}$ & $\begin{array}{c}0.025 \\
(0.979)\end{array}$ & $\begin{array}{c}0.020 \\
(0.674)\end{array}$ & $\begin{array}{c}0.044 \\
(1.347)\end{array}$ & $\begin{array}{l}-0.009 \\
(-0.285)\end{array}$ \\
\hline CRISIS & $\begin{array}{c}0.040 \\
(0.681)\end{array}$ & $\begin{array}{c}0.047 \\
(0.446)\end{array}$ & $\begin{array}{c}0.015 \\
(0.266)\end{array}$ & $\begin{array}{l}-0.004 \\
(-0.056)\end{array}$ & $\begin{array}{c}0.006 \\
(0.066)\end{array}$ & $\begin{array}{l}-0.006 \\
(-0.081)\end{array}$ \\
\hline $\begin{array}{l}\text { Macroeconomic interaction controls } \\
\text { Firm controls } \\
\text { Firm fixed effects } \\
\text { Year fixed effects }\end{array}$ & $\begin{array}{l}\text { Yes } \\
\text { Yes } \\
\text { Yes } \\
\text { Yes }\end{array}$ & $\begin{array}{l}\text { Yes } \\
\text { Yes } \\
\text { Yes } \\
\text { Yes }\end{array}$ & $\begin{array}{l}\text { Yes } \\
\text { Yes } \\
\text { Yes } \\
\text { Yes }\end{array}$ & $\begin{array}{l}\text { Yes } \\
\text { Yes } \\
\text { Yes } \\
\text { Yes }\end{array}$ & $\begin{array}{l}\text { Yes } \\
\text { Yes } \\
\text { Yes } \\
\text { Yes }\end{array}$ & $\begin{array}{l}\text { Yes } \\
\text { Yes } \\
\text { Yes } \\
\text { Yes }\end{array}$ \\
\hline $\begin{array}{l}\text { No. of obs. } \\
\text { Country cluster } \\
\text { Adj. } R^{2}\end{array}$ & $\begin{array}{c}19,892 \\
34 \\
0.114\end{array}$ & $\begin{array}{l}9,939 \\
32 \\
0.119\end{array}$ & $\begin{array}{c}9,953 \\
33 \\
0.120\end{array}$ & $\begin{array}{c}21,776 \\
34 \\
0.116\end{array}$ & $\begin{array}{c}10,773 \\
33 \\
0.097\end{array}$ & $\begin{array}{c}11,003 \\
34 \\
0.138\end{array}$ \\
\hline $\begin{array}{l}F \text {-statistic }\left(\beta \_ \text {High }-\beta \text { _Low }=0\right) \\
\text { Prob. }>\chi^{2}\end{array}$ & \multicolumn{3}{|c|}{$\begin{array}{l}0.74 \\
(0.391)\end{array}$} & & \multicolumn{2}{|c|}{$\begin{array}{c}3.07^{\star} \\
(0.080)\end{array}$} \\
\hline
\end{tabular}

\section{Trust and Firm Profitability and Employment during Banking Crises}

We now evaluate whether corporate profits and employment are more resilient to banking crises in economies with greater social trust. Social trust might shape corporate performance during crises through several mechanisms, including through trade credit. Specifically, by easing the ability of firms to access trade credit when bank credit dries up, social trust can mitigate the impact of banking crises on corporate profits and employment. There are other potential mechanisms. For example, economies with higher social trust might also be economies in which individuals and firms have strong trust in the ability of their government to manage banking crises. This mechanism suggests that trust could be linked to corporate resiliency to banking crises in a manner that does not involve trade credit. As another example, countries with high social trust might also tend to have stronger labor protections laws, and thus crises have less of an adverse impact on employment in such economics. In this section, we do not rule out all potential mechanisms linking social trust and corporate resiliency. Rather, our objectives are to assess i) whether corporate profits and employment are more resilient to banking crises in economies with greater social trust and ii) whether the relations between corporate profits and employment and social trust vary in a manner that is consistent with the trade-credit mechanism.

To conduct these examinations, we begin with equation (1) and use corporate profits and employment as dependent variables. Furthermore, we divide the 
sample into firms with high and low LIQUIDITY_NEEDS. If TRUST influences the resiliency of corporate profits and employment to a banking crisis by easing access to trade credit, then TRUST $\times$ CRISIS should only enter the regression positively and significantly when examining firms with high LIQUIDITY NEEDS. In addition to splitting the sample by LIQUIDITY_NEEDS and controlling for the array of macroeconomic and institutional controls discussed previously, we also account for two other potential mechanisms linking social trust and corporate profits and employment. We control for the interaction between the crisis dummy variable and i) an indicator of labor market protections and ii) an indicator of trust in the government. We first present the core results and then define these additional indicators and present the corresponding regression results.

As shown in Table 6, firms in industries with high LIQUIDITY_NEEDS in high-trust economies enjoy a smaller drop in profits (EBIT) than similar firms in low-trust countries. For example, consider column 2 for firms with high LIQUIDITY_NEEDS. The crisis dummy itself enters the regression negatively and significantly, meaning that banking crises on average lead to a reduction in firm profitability. However, the adverse effects of banking crises on profitability are less pronounced in high-trust economies, especially among firms with high liquidity needs, as shown by the positive and significant coefficient on TRUST $\times$ CRISIS.

The economic magnitude of the estimated impact of trust on firm profitability is substantial. Consider the coefficient estimates on the sample of

\section{TABLE 6}

\section{Social Trust and Firm Performance over Banking Crises}

\begin{tabular}{|c|c|c|c|c|c|c|}
\hline \multirow[b]{2}{*}{ Variable } & \multicolumn{3}{|c|}{ EBIT } & \multicolumn{3}{|c|}{ FIRM_EMPLOYMENT } \\
\hline & $\begin{array}{c}\text { All } \\
1\end{array}$ & $\begin{array}{l}\text { High } \\
\text { LIQUIDITY } \\
\text { NEEDS } \\
2\end{array}$ & $\begin{array}{l}\text { LOW } \\
\text { LIQUIDITY } \\
\text { NEEDS } \\
3\end{array}$ & $\begin{array}{c}\text { All } \\
4\end{array}$ & $\begin{array}{l}\text { High } \\
\text { LIQUIDITY } \\
\text { NEEDS } \\
5\end{array}$ & $\begin{array}{l}\text { Low } \\
\text { LIQUIDITY } \\
\text { NEEDS } \\
6\end{array}$ \\
\hline TRUST $\times$ CRISIS & $\begin{array}{l}0.072^{\star * *} \\
(2.924)\end{array}$ & $\begin{array}{l}0.126^{* * *} \\
(6.929)\end{array}$ & $\begin{array}{l}0.027 \\
(1.008)\end{array}$ & $\begin{array}{l}0.104 \\
(0.858)\end{array}$ & $\begin{array}{l}0.257^{\star \star} \\
(2.377)\end{array}$ & $\begin{array}{l}-0.058 \\
(-0.465)\end{array}$ \\
\hline CRISIS & $\begin{array}{l}-0.159^{* * *} \\
(-4.694)\end{array}$ & $\begin{array}{l}-0.280^{\star * *} \\
(-7.820)\end{array}$ & $\begin{array}{r}-0.080^{*} \\
(-1.896)\end{array}$ & $\begin{array}{l}-0.774^{* *} \\
(-2.108)\end{array}$ & $\begin{array}{l}-1.574^{\star \star \star} \\
(-5.824)\end{array}$ & $\begin{array}{l}-0.214 \\
(-0.555)\end{array}$ \\
\hline $\begin{array}{l}\text { Macroeconomic interaction controls } \\
\text { Firm controls } \\
\text { Firm fixed effects } \\
\text { Year fixed effects }\end{array}$ & $\begin{array}{l}\text { Yes } \\
\text { Yes } \\
\text { Yes } \\
\text { Yes }\end{array}$ & $\begin{array}{l}\text { Yes } \\
\text { Yes } \\
\text { Yes } \\
\text { Yes }\end{array}$ & $\begin{array}{l}\text { Yes } \\
\text { Yes } \\
\text { Yes } \\
\text { Yes }\end{array}$ & $\begin{array}{l}\text { Yes } \\
\text { Yes } \\
\text { Yes } \\
\text { Yes }\end{array}$ & $\begin{array}{l}\text { Yes } \\
\text { Yes } \\
\text { Yes } \\
\text { Yes }\end{array}$ & $\begin{array}{l}\text { Yes } \\
\text { Yes } \\
\text { Yes } \\
\text { Yes }\end{array}$ \\
\hline $\begin{array}{l}\text { No. of obs. } \\
\text { Country cluster } \\
\text { Adj. } R^{2}\end{array}$ & $\begin{array}{c}23,177 \\
34 \\
0.115\end{array}$ & $\begin{array}{c}11,572 \\
34 \\
0.127\end{array}$ & $\begin{array}{c}11,605 \\
34 \\
0.111\end{array}$ & $\begin{array}{c}20,982 \\
34 \\
0.221\end{array}$ & $\begin{array}{c}10,463 \\
32 \\
0.262\end{array}$ & $\begin{array}{c}10,519 \\
34 \\
0.186\end{array}$ \\
\hline $\begin{array}{l}\text { F-statistic }\left(\beta \_ \text {High }-\beta \_ \text {Low }=0\right) \\
\text { Prob. }>\chi^{2}\end{array}$ & \multicolumn{3}{|c|}{$\begin{array}{c}28.39^{\star \star *} \\
(0.000)\end{array}$} & & \multicolumn{2}{|c|}{$\begin{array}{l}10.44^{\star \star \star} \\
(0.001)\end{array}$} \\
\hline
\end{tabular}


firms in industries with high LIQUIDITY_NEEDS (column 2 of Table 6). The estimates suggest that a 1-standard-deviation increase in the measure of trust $(0.168)$ leads to a 2-percentage-point $(=0.168 \times 0.126)$ increase in EBIT. This amount is equivalent to $37 \%$ of the sample mean of EBIT (0.057), as shown in Table 1 , and $18 \%$ of the standard deviation of EBIT (0.12). To further illustrate the economic size, consider i) an "average" country that has average values of TRUST, GDP_PER_CAPITA, FINANCIAL_INSTITUTION_DEVELOPMENT, STOCK_MARKET_DEVELOPMENT, PRIVATE_CREDIT_CONTRACTION, ANTI_SELF_DEALING, and CREDITOR_RIGHTS and ii) a "high-trust" country with the same levels of all country characteristics except that TRUST is 1 standard deviation higher than the sample average, $0.496(=0.328+0.168)$. According to the coefficient estimates in column 2, a banking crisis reduces EBIT on average by about $4 \%$ for the average country and by $2 \%$ for the high-trust country. ${ }^{7}$ Thus, EBIT among firms in industries with high LIQUIDITY_NEEDS in the high-trust country falls by approximately $50 \%$ less during banking crises compared with similar firms in countries with average levels of social trust.

Besides profits, social trust could also affect employment. If social trust eases a firm's access to trade credit when bank credit contracts during a crisis, then this could reduce the adverse effects of banking crises on firm employment. Thus, we test whether firms in industries with high LIQUIDITY_NEEDS in economies with higher social trust have a smaller drop in employment during a banking crisis than similar firms in countries with lower social trust.

We find that firms with high LIQUIDITY_NEEDS in high-trust countries experience a smaller drop in FIRM_EMPLOYMENT during banking crises than similar firms in low-trust countries. As shown in column 5 of Table 6 , the interaction term, TRUST $\times$ CRISIS, enters positively and significantly at the $5 \%$ level in the industries with high LIQUIDITY_NEEDS, indicating that trust helps mitigate the adverse shock of a crisis on FIRM_EMPLOYMENT among industries that rely heavily on liquidity provisions. In contrast, and consistent with the theory of how social trust influences corporate resilience by facilitating access to trade credit, column 6 shows that the coefficient estimate on TRUST $\times$ CRISIS is insignificant in the industries with low LIQUIDITY_NEEDS.

The estimated magnitudes are large. ${ }^{8}$ Again, consider an "average" country and a "high-trust" country that is the same as the average country except that it has 1-standard-deviation-higher value for TRUST. According to the OLS estimates in column 5 of Table 6 , a banking crisis reduces corporate employment among firms with high LIQUIDITY_NEEDS by $25 \%$ in the average country but by $20 \%$

\footnotetext{
${ }^{7}$ We calculate the average effect of a banking crisis on EBIT by plugging the sample means of the macro variables and the corresponding coefficient estimates from column 2 of Table 6: $-4.09 \%(=0.126 \times 0.328-0.28+0.0208 \times 9.211-0.03 \times 0.807+0.00000148 \times 0.579-$ $0.0275 \times 0.287+0.0894 \times 0.44-0.000518 \times 2.059)$. In similar fashion, we calculate the effect of a banking crisis for the high-trust country using the corresponding coefficients in column 2 : $-1.97 \% \quad(=0.126 \times 0.496-0.28+0.0208 \times 9.211-0.03 \times 0.807+0.00000148 \times 0.579-0.0275 \times$ $0.287+0.0894 \times 0.44-0.000518 \times 2.059)$.

${ }^{8}$ Note that we can interpret the coefficients in percentage changes because FIRM_EMPLOYMENT is defined as the natural logarithm of the total number of employees in a firm.
} 
in the high-trust country. ${ }^{9}$ Thus, among firms with high LIQUIDITY_NEEDS, employment falls by almost $20 \%$ less during a systemic banking crisis in the hightrust country.

These results on corporate profits and employment are robust to many factors. First, the Table 6 regressions condition on the macroeconomic interaction controls; that is, the regressions include the interactions between CRISIS and i) GDP_PER_CAPITA, ii) FINANCIAL_INSTITUTION_DEVELOPMENT, iii) STOCK_MARKET_DEVELOPMENT, iv) PRIVATE_CREDIT CONTRACTION, v) ANTI_SELF_DEALING, and vi) CREDITOR_RIGHTS. Furthermore, the regressions include firm and year fixed effects, as well as timevarying firm controls (FIRM_SIZE, LONG_TERM_DEBT, and TOBINS_Q). Second, Table 7 shows that the results are robust to controlling for the level of development of formal institutions. As in Table 3, Table 7 (columns 1-4 of Panels $\mathrm{A}$ and $\mathrm{B}$ ) controls for the interaction between CRISIS and RULE_OF_LAW and INSTITUTIONAL_QUALITY and demonstrates that all of the results hold. ${ }^{10}$ Third, the results are robust to examining alternative measures of firm performance, such as NET_INCOME and corporate CASH_FLOW (Internet Appendix Table IA8), or to using alternative measures of the technological level of liquidity needs, such as INVENTORIES/COGS and TRADE_CREDIT_RELIANCE (Internet Appendix Table IA9).

As discussed previously, we are concerned that social trust might be correlated with labor protection laws and that it is these labor protection laws, not social trust per se, that shape the resilience of corporate employment during banking crises. To address this concern, we use data on the degree to which each country's labor laws and regulations restrict the ability of firms to dismiss individuals or groups of workers. These data are from the Organisation for Economic Co-Operation and Development (OECD) Employment Protection Database, but we also cover non-OECD countries. LABOR_PROTECTION_LAWS is an index that ranges between 0 and 6 , where higher values indicate greater labor market protections. The index includes information on i) procedural impediments employers face when starting to fire workers, such as notification procedures; ii) the length of the notice period and the generosity of severance pay; iii) the difficulty of dismissal, as determined by the circumstances in which it is justifiable to fire a worker and the compensation and possibilities of reinstatement following unfair dismissal; and iv) additional costs and impediments to dismissing a large number of workers. Thus, in addition to all of the controls included in Table 6, we also include the interaction between CRISIS and LABOR_PROTECTION_LAWS in

\footnotetext{
${ }^{9} \mathrm{We}$ calculate the average effect of a systemic banking crisis by plugging in the sample average values and the corresponding coefficient estimates using column 5 of Table 6: $-24.6 \% \quad(=0.257 \times 0.328-1.574+0.126 \times 9.211+0.0818 \times 0.807-0.0583 \times 0.579+0.155 \times$ $0.287+0.191 \times 0.44-0.0377 \times 2.059)$. Similarly, for the high-trust country, we plug in TRUST with a value that is 1 standard deviation above the sample mean while holding other country characteristics at their mean values: $-20.3 \%(=0.257 \times 0.496-1.574+0.126 \times 9.211+0.0818 \times 0.807-0.0583 \times$ $0.579+0.155 \times 0.287+0.191 \times 0.44-0.0377 \times 2.059)$.

${ }^{10}$ As shown in Table IA10 of the Internet Appendix, all of these results hold when using the two alternative metrics for differentiating between high- and low-liquidity-needs industries: INVENTORIES/COGS and TRADE_CREDIT_RELIANCE.
} 
Table 7 (columns 5-6 of Panels A and B), where we continue to split the sample based on the median value of the industrial LIQUIDITY_NEEDS.

As shown in Table 7, all of the results reported in Table 6 hold when controlling for LABOR_PROTECTION_LAWS. In the sample with high LIQUIDITY_NEEDS, TRUST $\times$ CRISIS enters positively and significantly in both the corporate profit and employment regressions. Furthermore, the estimated coefficients are similar to those reported previously. The results also highlight the role of labor regulations during crises. As reported in Panel B of Table 7 (column 5), the coefficient on LABOR_PROTECTION_LAWS $\times$ CRISIS enters positively and significantly. This finding suggests that stringent labor regulations are associated with smaller reductions in corporate employment during banking crises.

\title{
TABLE 7
}

\section{Social Trust and Firm Performance: Additional Controls}

\begin{abstract}
Table 7 reports regression results of the relation between social trust and profits and employment during banking crises while controlling for laws and institutions, namely, the interaction of CRISIS and i) RULE_OF_LAW, ii) INSTITUTIONAL_QUALITY, iii) LABOR_PROTECTION_LAWS, and iv) TRUST_IN_GOVERNMENT. The dependent variables are the earnings before income and taxes (EBIT) in Panel $A$ and the natural logarithm of the number of 1,000 employees (FIRM_EMPLOYMENT) in Panel B. For each dependent variable, results are provided for both high- and low-liquidity-needs industries, where we partition industries by the median value of LIQUIDITY_NEEDS, which equals the ratio of inventories to total sales calculated at the 3-digit Standard Industrial Classification (SIC) level (Raddatz (2006)). CRISIS equals 1 in the start year of a crisis and for the 3 years afterward, $[t, t+3]$, and 0 otherwise, $[t-3, t-1]$. RULE_OF_LAW measures the quality of contract enforcement, property rights, and control over crime and violence; INSTITUTIONAL_QUALITY is a broad index of institutional quality, including property rights, voice of accountability, political stability and absence of violence, government effectiveness, regulatory quality, rule of law, and control of corruption; LABOR_PROTECTION_LAWS measures the costs and impediments employers face when dismissing workers; and TRUST_IN_GOVERNMENT measures the average degree of confidence people have in their government. The macroeconomic interaction controls include CRISIS interacted with the following: GDP_PER_CAPITA, FINANCIAL_INSTITUTION_DEVELOPMENT, STOCK_MARKET_DEVELOPMENT, PRIVATE_CREDIT_CONTRACTION, ANTI_SELF_DEALING, and CREDITOR_RIGHTS. The firm controls include the following: FIRM SIZE (lag), LONG TERM DEBT (lag), and TOBINS Q (lag). Variable definitions are provided in the Appendix. Regression coefficients are estimated using ordinary least squares (OLS). $t$-statistics are reported in parentheses and calculated using robust standard errors clustered at the country level. ${ }^{* *}$, ${ }^{* *}$, and ${ }^{*}$ indicate significance at the $1 \%, 5 \%$, and $10 \%$ levels, respectively.
\end{abstract}

Panel A. Firm Profits

\begin{tabular}{|c|c|c|c|c|c|c|c|c|}
\hline & \multicolumn{8}{|c|}{ EBIT } \\
\hline & $\begin{array}{c}\text { High } \\
\text { LIQUIDITY } \\
\text { NEEDS }\end{array}$ & $\begin{array}{l}\text { Low } \\
\text { LIQUIDITY } \\
\text { NEEDS }\end{array}$ & $\begin{array}{l}\text { High } \\
\text { LIQUIDITY } \\
\text { NEEDS }\end{array}$ & $\begin{array}{l}\text { Low } \\
\text { LIQUIDITY } \\
\text { NEEDS }\end{array}$ & $\begin{array}{l}\text { High } \\
\text { LIQUIDITY } \\
\text { NEEDS }\end{array}$ & $\begin{array}{l}\text { Low } \\
\text { LIQUIDITY } \\
\text { NEEDS }\end{array}$ & $\begin{array}{l}\text { High } \\
\text { LIQUIDITY } \\
\text { NEEDS }\end{array}$ & $\begin{array}{l}\text { Low } \\
\text { LIQUIDITY } \\
\text { NEEDS }\end{array}$ \\
\hline Variable & 1 & 2 & 3 & 4 & 5 & 6 & 7 & 8 \\
\hline TRUST $\times$ CRISIS & $\begin{array}{l}0.109^{\star \star \star} \\
(5.052)\end{array}$ & $\begin{array}{c}0.020 \\
(0.735)\end{array}$ & $\begin{array}{l}0.103^{\star \star \star} \\
(5.092)\end{array}$ & $\begin{array}{c}0.021 \\
(0.806)\end{array}$ & $\begin{array}{l}0.129^{\star \star \star} \\
(6.645)\end{array}$ & $\begin{array}{c}0.039 \\
(1.669)\end{array}$ & $\begin{array}{l}0.148^{\star \star \star} \\
(6.189)\end{array}$ & $\begin{array}{c}0.044 \\
(1.382)\end{array}$ \\
\hline CRISIS & $\begin{array}{l}-0.230^{\star \star \star} \\
(-6.531)\end{array}$ & $\begin{array}{c}-0.062 \\
(-1.485)\end{array}$ & $\begin{array}{l}-0.192^{\star \star \star} \\
(-5.760)\end{array}$ & $\begin{array}{l}-0.056 \\
(-1.277)\end{array}$ & $\begin{array}{l}-0.243^{\star \star \star} \\
(-3.042)\end{array}$ & $\begin{array}{l}-0.080 \\
(-1.307)\end{array}$ & $\begin{array}{l}-0.301^{\star \star \star} \\
(-7.980)\end{array}$ & $\begin{array}{l}-0.110^{\star \star} \\
(-2.172)\end{array}$ \\
\hline RULE_OF_LAW $\times$ CRISIS & $\begin{array}{l}0.016^{\star \star} \\
(2.673)\end{array}$ & $\begin{array}{c}0.008 \\
(1.369)\end{array}$ & & & & & & \\
\hline $\begin{array}{l}\text { INSTITUTIONAL } \\
\text { QUALITY } \times \text { CRISIS }\end{array}$ & & & $\begin{array}{l}0.008^{\star \star \star} \\
(3.612)\end{array}$ & $\begin{array}{c}0.002 \\
(0.857)\end{array}$ & & & & \\
\hline $\begin{array}{l}\text { LABOR_PROTECTION_ } \\
\text { LAWS } \times \text { CRISIS }\end{array}$ & & & & & $\begin{array}{c}-0.007 \\
(-0.631)\end{array}$ & $\begin{array}{l}-0.007 \\
(-0.840)\end{array}$ & & \\
\hline $\begin{array}{l}\text { TRUST_IN } \\
\text { GOVERNMENT } \times \text { CRISIS }\end{array}$ & & & & & & & $\begin{array}{c}0.029 \\
(1.350)\end{array}$ & $\begin{array}{c}0.022 \\
(1.132)\end{array}$ \\
\hline $\begin{array}{l}\text { Macroeconomic } \\
\text { interaction controls }\end{array}$ & Yes & Yes & Yes & Yes & Yes & Yes & Yes & Yes \\
\hline Firm controls & Yes & Yes & Yes & Yes & Yes & Yes & Yes & Yes \\
\hline Firm fixed effects & Yes & Yes & Yes & Yes & Yes & Yes & Yes & Yes \\
\hline Year fixed effects & Yes & Yes & Yes & Yes & Yes & Yes & Yes & Yes \\
\hline $\begin{array}{l}\text { No. of obs. } \\
\text { Country cluster }\end{array}$ & $\begin{array}{c}11,572 \\
34\end{array}$ & $\begin{array}{c}11,605 \\
34\end{array}$ & $\begin{array}{c}11,572 \\
34\end{array}$ & $\begin{array}{c}11,605 \\
34\end{array}$ & $\begin{array}{c}11,404 \\
31\end{array}$ & $\begin{array}{c}11,448 \\
31\end{array}$ & $\begin{array}{c}11,572 \\
34\end{array}$ & $\begin{array}{c}11,605 \\
34\end{array}$ \\
\hline Adj. $R^{2}$ & 0.128 & 0.111 & 0.128 & 0.111 & 0.121 & 0.116 & 0.127 & 0.112 \\
\hline $\begin{array}{l}\text { F-statistic } \\
\quad\left(\beta \_ \text {High }-\beta \_ \text {Low }=0\right)\end{array}$ & 15.4 & $8^{\star \star \star}$ & 12.7 & $9^{\star \star \star}$ & 43. & $0^{\star \star \star}$ & 17. & $1^{\star \star \star}$ \\
\hline Prob. $>\chi^{2}$ & $(0.0$ & & $(0 . C$ & 00) & $(0.0$ & 00) & $(0.0$ & 00) \\
\hline
\end{tabular}


TABLE 7 (continued)

Social Trust and Firm Performance: Additional Controls

\begin{tabular}{|c|c|c|c|c|c|c|c|c|}
\hline \multirow[b]{3}{*}{ Variable } & \multicolumn{8}{|c|}{ FIRM_EMPLOYMENT } \\
\hline & $\begin{array}{l}\text { High } \\
\text { LIQUIDITY } \\
\text { NEEDS }\end{array}$ & $\begin{array}{l}\text { Low } \\
\text { LIQUIDITY_ } \\
\text { NEEDS }\end{array}$ & $\begin{array}{c}\text { High } \\
\text { LIQUIDITY_- } \\
\text { NEEDS }\end{array}$ & $\begin{array}{l}\text { Low } \\
\text { LIQUIDITY_ } \\
\text { NEEDS }\end{array}$ & $\begin{array}{c}\text { High } \\
\text { LIQUIDITY } \\
\text { NEEDS }\end{array}$ & $\begin{array}{l}\text { Low } \\
\text { LIQUIDITY } \\
\text { NEEDS }\end{array}$ & $\begin{array}{c}\text { High } \\
\text { LIQUIDITY } \\
\text { NEEDS }\end{array}$ & $\begin{array}{l}\text { Low } \\
\text { LIQUIDITY } \\
\text { NEEDS }\end{array}$ \\
\hline & 1 & 2 & 3 & 4 & 5 & 6 & 7 & 8 \\
\hline TRUST $\times$ CRISIS & $\begin{array}{l}0.293^{\star \star \star} \\
(2.771)\end{array}$ & $\begin{array}{l}-0.107 \\
(-0.791)\end{array}$ & $\begin{array}{l}0.269^{\star *} \\
(2.557)\end{array}$ & $\begin{array}{l}-0.121 \\
(-0.843)\end{array}$ & $\begin{array}{l}0.242^{\star \star} \\
(2.309)\end{array}$ & $\begin{array}{l}-0.021 \\
(-0.181)\end{array}$ & $\begin{array}{l}0.407^{\star \star \star} \\
(4.595)\end{array}$ & $\begin{array}{c}0.008 \\
(0.043)\end{array}$ \\
\hline CRISIS & $\begin{array}{l}-1.705^{\star \star \star} \\
(-5.491)\end{array}$ & $\begin{array}{l}-0.035 \\
(-0.082)\end{array}$ & $\begin{array}{l}-1.628^{\star \star \star} \\
(-4.650)\end{array}$ & $\begin{array}{c}0.080 \\
(0.162)\end{array}$ & $\begin{array}{l}-2.512^{\star \star \star} \\
(-6.101)\end{array}$ & $\begin{array}{l}-0.616 \\
(-0.954)\end{array}$ & $\begin{array}{l}-1.698^{\star \star \star} \\
(-8.309)\end{array}$ & $\begin{array}{l}-0.308 \\
(-0.780)\end{array}$ \\
\hline RULE_OF_LAW $\times$ CRISIS & $\begin{array}{l}-0.037 \\
(-0.801)\end{array}$ & $\begin{array}{c}0.062 \\
(0.712)\end{array}$ & & & & & & \\
\hline $\begin{array}{l}\text { INSTITUTIONAL } \\
\text { QUALITY } \times \text { CRISIS }\end{array}$ & & & $\begin{array}{l}-0.005 \\
(-0.256)\end{array}$ & $\begin{array}{c}0.028 \\
(0.790)\end{array}$ & & & & \\
\hline $\begin{array}{l}\text { LABOR_PROTECTION } \\
\text { LAWS } \times \text { CRISIS }\end{array}$ & & & & & $\begin{array}{l}0.159^{\star \star} \\
(2.475)\end{array}$ & $\begin{array}{l}0.034 \\
(0.411)\end{array}$ & & \\
\hline $\begin{array}{l}\text { TRUST_IN_- } \\
\text { GOVERNMENT } \times \text { CRISIS }\end{array}$ & & & & & & & $\begin{array}{r}0.178^{\star} \\
(1.948)\end{array}$ & $\begin{array}{c}0.074 \\
(0.448)\end{array}$ \\
\hline $\begin{array}{l}\text { Macroeconomic } \\
\text { interaction controls }\end{array}$ & Yes & Yes & Yes & Yes & Yes & Yes & Yes & Yes \\
\hline Firm controls & Yes & Yes & Yes & Yes & Yes & Yes & Yes & Yes \\
\hline Firm fixed effects & Yes & Yes & Yes & Yes & Yes & Yes & Yes & Yes \\
\hline Year fixed effects & Yes & Yes & Yes & Yes & Yes & Yes & Yes & Yes \\
\hline $\begin{array}{l}\text { No. of obs. } \\
\text { Country cluster }\end{array}$ & $\begin{array}{c}10,463 \\
32\end{array}$ & $\begin{array}{c}10,519 \\
34\end{array}$ & $\begin{array}{c}10,463 \\
32\end{array}$ & $\begin{array}{c}10,519 \\
34\end{array}$ & $\begin{array}{c}10,314 \\
29\end{array}$ & $\begin{array}{c}10,399 \\
31\end{array}$ & $\begin{array}{c}10,463 \\
32\end{array}$ & $\begin{array}{c}10,519 \\
34\end{array}$ \\
\hline Adj. $R^{2}$ & 0.262 & 0.187 & 0.262 & 0.187 & 0.265 & 0.189 & 0.263 & 0.186 \\
\hline $\begin{array}{l}F \text {-statistic } \\
\qquad\left(\beta \_ \text {High }-\beta \_ \text {Low }=0\right)\end{array}$ & 15. & $8^{\star \star \star}$ & 12.3 & $7^{\star \star \star}$ & & $2^{\star \star \star}$ & & $7^{\star \star}$ \\
\hline Prob. $>\chi^{2}$ & $(0.0$ & $00)$ & $(0.0$ & 00) & $(0.0$ & 07) & $(0.0$ & 17) \\
\hline
\end{tabular}

We also explore whether the results are driven by a strong correlation between social trust and trust in government's ability to resolve a banking crisis. As noted, if firms and individuals have greater trust that the government will quickly and effectively fix the banking crisis, then corporate profits and employment may tend to fall less than if the public has less trust in the competency of the government. Thus, our results might reflect trust in government rather than social trust and potential linkages through trade credit. We partially address this concern by showing that the results only hold for firms with high LIQUIDITY_NEEDS and by controlling for the interaction between CRISIS and many country traits. But we also push this further by including a separate interaction term: TRUST_IN_GOVERNMENT $\times$ CRISIS, where TRUST_IN_GOVERNMENT is a measure of the degree to which people trust the government that is taken from the WVS. It measures the degree of confidence people have in the government and is based on asking people the following question: "How much confidence do you have in the government: is it a great deal of confidence, quite a lot of confidence, not very much confidence or none at all?" We use the value in year $t-3$, where $t$ is the start year of a banking crisis.

As shown in Table 7 (columns 7-8 of Panels A and B), all of the results hold when controlling for TRUST_IN_GOVERNMENT $\times$ CRISIS. That is, TRUST $\times$ CRISIS enters positively and significantly in both the corporate profit and employment regressions in the sample of firms with high LIQUIDITY_NEEDS. Furthermore, the estimated coefficients are similar in magnitude to those reported in Table 6. These findings suggest that the results in Table 6 are not simply driven by people's confidence in the government. 
Finally, we also note that the results are robust to controlling for differential trends, as shown in Table 8 . In a series of sensitivity analyses, we add to the regressions the interactions between time trends (TRENDS) and i) country effects, ii) country-industry effects, and iii) firm effects. Panel A provides the results on profits, and Panel B provides the results on firm employment. All of the results on both profits and employment from Table 6 hold when conditioning on either COUNTRY_DUMMY $\times$ TRENDS or COUNTRY_INDUSTRY _ DUMMY $\times$ TRENDS, as shown Table 8 . The results on profits also hold when including FIRM_DUMMY $\times$ TRENDS effects. When examining employment and controlling for FIRM_DUMMY $\times$ TRENDS, as well as the other control variables, we continue to find that $i$ ) the TRUST $\times$ CRISIS interaction terms enter positively and significantly, inducting that corporate employment is more resilient to systemic banking crises in high-trust economies, and ii) the point estimates for the industries with high LIQUIDITY_NEEDS are greater than those in the industries with low LIQUIDITY_NEEDS, but the difference between the industries with

TABLE 8

Social Trust and Firm Performance over Banking Crises: Controlling for Time Trends

Table 8 reports regression results of the relation between social trust and firms' profits and employment during banking crises while controlling for differential trends within country, country-industry, and individual firms. The dependent variables are the earnings before income and taxes (EBIT) in Panel A and the natural logarithm of the number of 1,000 employees (FIRM_EMPLOYMENT) in Panel B. For each set of time-trend controls, there are three columns corresponding to, respectively, the overall sample, high-liquidity-needs industries, and low-liquidity-needs industries, where we partition industries by the median value of LIQUIDITY_NEEDS, which equals the ratio of inventories to total sales calculated at the 3-digit Standard Industrial Classification (SIC) level (Raddatz (2006)). CRISIS equals 1 in the start year of a crisis and for the 3 years afterward, $[t, t+3]$, and 0 otherwise, $[t-3, t-1]$. For both panels, columns $1-3$ control for the interaction between COUNTRY_DUMMY and the time-trend variable, TRENDS, indicating one of the years over [ $t-3, t+3]$. In particular, TRENDS is set to 1 for $t-3,2$ for $t-2,3$ for $t-3,4$ for $t, 5$ for $t+1,6$ for $t+2$, and 7 for $t+3$. Columns $4-6$ control for the interaction between COUNTRY INDUSTRY DUMMY (at the 3-digit SIC level) and TRENDS. Columns 7-9 control for the interaction between FIRM_DUMMY and TRENDS. The macroeconomic interaction controls include CRISIS interacted with the following: GDP_PER_CAPITA, FINANCIAL_INSTITUTION_DEVELOPMENT, STOCK_MARKET_DEVELOPMENT, PRIVATE_CREDIT_CONTRACTION, ANTI_SELF_DEALING, and CREDITOR_RIGHTS. The firm controls include the following: FIRM_SIZE (lag), LONG_TERM_DEBT (lag), and TOBINS_Q (lag). Variable definitions are provided in the Appendix. Regression coefficients are estimated using ordinary least squares (OLS). $t$-statistics are reported in parentheses and calculated using robust standard errors clustered at the country level. ${ }^{* * *},{ }^{* *}$, and ${ }^{*}$ indicate significance at the $1 \%, 5 \%$, and $10 \%$ levels, respectively.

Panel A. Firm Profits

\begin{tabular}{|c|c|c|c|c|c|c|c|c|c|}
\hline \multirow{3}{*}{ Variable } & \multicolumn{9}{|c|}{ EBIT } \\
\hline & All & $\begin{array}{c}\text { High } \\
\text { LIQUIDITY } \\
\text { NEEDS }\end{array}$ & $\begin{array}{l}\text { Low } \\
\text { LIQUIDITY } \\
\text { NEEDS }\end{array}$ & All & $\begin{array}{c}\text { High } \\
\text { LIQUIDITY } \\
\text { NEEDS }\end{array}$ & $\begin{array}{l}\text { Low } \\
\text { LIQUIDITY_- } \\
\text { NEEDS }\end{array}$ & All & $\begin{array}{c}\text { High } \\
\text { LIQUIDITY } \\
\text { NEEDS }\end{array}$ & $\begin{array}{l}\text { Low } \\
\text { LIQUIDITY } \\
\text { NEEDS }\end{array}$ \\
\hline & 1 & 2 & 3 & 4 & 5 & 6 & 7 & 8 & 9 \\
\hline TRUST $\times$ CRISIS & $\begin{array}{c}0.055 \\
(1.691)\end{array}$ & $\begin{array}{l}0.126^{\star \star \star} \\
(3.985)\end{array}$ & $\begin{array}{c}-0.013 \\
(-0.419)\end{array}$ & $\begin{array}{r}0.057^{\star} \\
(1.726)\end{array}$ & $\begin{array}{l}0.129^{\star \star \star} \\
(3.946)\end{array}$ & $\begin{array}{c}-0.013 \\
(-0.402)\end{array}$ & $\begin{array}{c}0.044 \\
(1.242)\end{array}$ & $\begin{array}{l}0.104^{\star \star \star} \\
(2.940)\end{array}$ & $\begin{array}{c}-0.017 \\
(-0.521)\end{array}$ \\
\hline CRISIS & $\begin{array}{c}0.023 \\
(0.332)\end{array}$ & $\begin{array}{l}-0.038 \\
(-0.431)\end{array}$ & $\begin{array}{c}0.084 \\
(1.286)\end{array}$ & $\begin{array}{c}0.041 \\
(0.573)\end{array}$ & $\begin{array}{c}-0.031 \\
(-0.345)\end{array}$ & $\begin{array}{c}0.098 \\
(1.510)\end{array}$ & $\begin{array}{c}0.059 \\
(0.777)\end{array}$ & $\begin{array}{c}0.003 \\
(0.027)\end{array}$ & $\begin{array}{c}0.096 \\
(1.420)\end{array}$ \\
\hline $\begin{array}{l}\text { Macroeconomic } \\
\text { interaction controls }\end{array}$ & Yes & Yes & Yes & Yes & Yes & Yes & Yes & Yes & Yes \\
\hline Firm controls & Yes & Yes & Yes & Yes & Yes & Yes & Yes & Yes & Yes \\
\hline Firm fixed effects & Yes & Yes & Yes & Yes & Yes & Yes & Yes & Yes & Yes \\
\hline Year fixed effects & Yes & Yes & Yes & Yes & Yes & Yes & Yes & Yes & Yes \\
\hline COUNTRY_DUMMY $\times$ TRENDS & Yes & Yes & Yes & & & & & & \\
\hline $\begin{array}{l}\text { COUNTRY_INDUSTRY } \\
\text { DUMMY } \times \text { TRENDS }\end{array}$ & & & & Yes & Yes & Yes & & & \\
\hline FIRM_DUMMY $\times$ TRENDS & & & & & & & Yes & Yes & Yes \\
\hline No. of obs. & 23,177 & 11,572 & 11,605 & 23,177 & 11,572 & 11,605 & 23,177 & 11,572 & 11,605 \\
\hline Country cluster & 34 & 34 & 34 & 34 & 34 & 34 & 34 & 34 & 34 \\
\hline Adj. $R^{2}$ & 0.125 & 0.138 & 0.123 & 0.196 & 0.214 & 0.181 & 0.338 & 0.349 & 0.332 \\
\hline $\begin{array}{l}F \text {-statistic } \\
\qquad\left(\beta \_ \text {High }-\beta \text { _Low }=0\right)\end{array}$ & & 26.3 & $30^{\star \star \star}$ & & 24.4 & $0^{\star \star \star}$ & & 18.4 & *夫 \\
\hline Prob. $>\chi^{2}$ & & $(0.0$ & $000)$ & & $(0.0$ & $00)$ & & $(0.0$ & $00)$ \\
\hline
\end{tabular}


TABLE 8 (continued)

Social Trust and Firm Performance over Banking Crises: Controlling for Time Trends

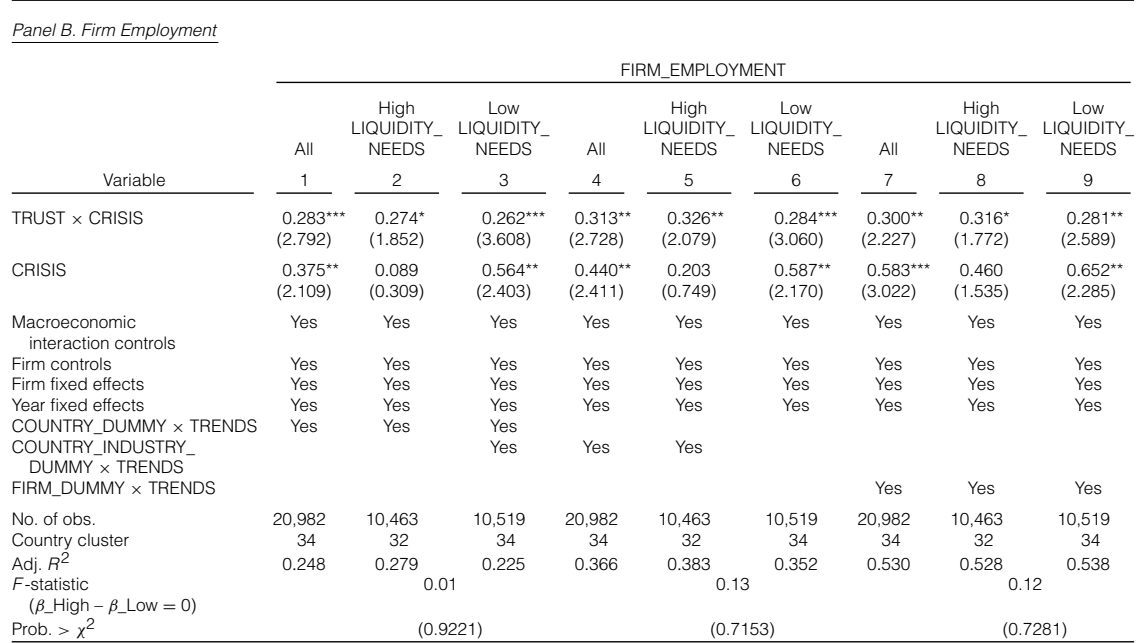

high and low LIQUIDITY_NEEDS in these employment regressions when controlling for individual firm trends is not statistically significant. With this caveat, the results on the connection between social trust and corporate resilience to systemic banking crises are quite robust to controlling for trends.

\section{Conclusion}

In this article, we investigate whether social trust improves corporate resilience to systemic banking crises. Although there are enormous bodies of research on both financial crises and social trust, we are unaware of any previous research on the role of social trust in affecting the response of firms and economies to systemic banking crises.

The results suggest that i) social trust facilitates access to trade credit during systemic banking crises that impede the normal bank-lending channel, ii) social trust makes corporate profits and employment more resilient to banking crises, and iii) the impact of social trust on trade-credit financing and corporate performance is more pronounced among firms that, for technological reasons, rely heavily on short-term liquidity. The findings are not explained by other country characteristics, including i) the severity of a banking crisis, ii) the development of financial institutions and stock markets, iii) the legal protections pertaining to creditors and shareholders, iv) the overall economic conditions, and v) the general legal rules and institutional quality. The results emphasize the heterogeneous response of firms and economies to systemic banking crises. Along with Levine et al. (2016), this article shows that economies and firms that facilitate nonbank forms of finance increase resiliency to failures in the banking system. 


\section{Appendix. Variable Definitions and Sources}

\section{Social Capital}

TRUST: Assessed by asking people the following question: "Generally speaking, would you say that most people can be trusted, or that you can't be too careful in dealing with people?" We calculate as the level of trust the percentage of respondents in each nation choosing the option of "most people can be trusted." We use the trust level at $t-3$, where $t$ is the start year of a banking crisis. Source: WVS.

\section{Systemic Banking Crises}

CRISIS: Equals 1 at the start year of a crisis and 3 years after, $[t, t+3]$. The start year of a systemic banking crisis shows significant signs of banking-sector distress and significant policy intervention. Source: Laeven and Valencia (2013), International Monetary Fund (IMF).

Firm-Level Variables

TRADE_CREDIT_FINANCING/COGS: Accounts payable at the end of period $t$ minus accounts payment at the beginning of period $t / \cos t$ of goods sold during period $t$. Source: Worldscope.

TRADE_CREDIT_FINANCING/TOTAL_ASSETS: Accounts payable at the end of period $t$ minus accounts payment at the beginning of period $t /$ book value of total assets at the beginning of period $t$. Source: Worldscope.

DEBT_ISSUANCE: Total debt at the end of period $t$ minus total debt at the beginning of period $t /$ book value of total assets at the beginning of period $t$, where total debt equals the sum of short-term debt and long-term debt excluding capitalized leases. Source: Worldscope.

EQUITY_ISSUANCE: $(\triangle$ COMMON_EQUITY $+\triangle$ DEFERRED_TAX $-\triangle$ RETAINED_ EARNINGS)/book value of total assets at the beginning of period $t$, where $\triangle$ COMMON_EQUITY equals common equity at the end of period $t$ minus common equity at the beginning of period $t, \triangle$ DEFERRED_TAX equals deferred tax at the end of period $t$ minus deferred tax at the beginning of period $t, \triangle$ DEFERRED_TAX is treated as 0 when missing, and $\triangle$ RETAINED_EARNINGS equals retained earnings at the end of period $t$ minus retained earnings at the beginning of period $t$. Source: Worldscope.

EBIT: Earnings before interest and taxes during period $t /$ book value of total assets at the beginning of period $t$. Source: Worldscope.

NET_INCOME: Net income after dividends/book value of total assets at the beginning of period $t$. Source: Worldscope.

CASH_FLOW: (Net income after dividends + depreciation and amortization) during period $t$ /book value of total assets at the beginning of period $t$. Source: Worldscope.

FIRM_EMPLOYMENT: Natural logarithm of the number of 1,000 employees, so for a firm with 1,000 or fewer employees, FIRM_EMPLOYMENT equals 0. Source: Worldscope.

FIRM_SIZE: Natural logarithm of the book value of total assets. Source: Worldscope.

LONG_TERM_DEBT: Long-term debt/book value of total assets. Source: Worldscope.

TOBINS_Q: Natural logarithm of market value of total assets/book value of total assets, where market value of total assets equals market value of equity plus book value of assets minus book value of equity, and market value of equity equals the stock price at the end of period $t$ multiplied by the total number outstanding shares. Source: Worldscope. 
Industry-Level Characteristics

LIQUIDITY_NEEDS: We use the U.S. data over a 10-year window, $[t-10, t-1]$, for each crisis country to construct the index, where $t$ is the start year of the crisis. We first compute the ratio of inventories to sales for each U.S. manufacturing firm and obtain in each firm the median value of the ratio over its 10-year window. Then we take the median ratio across firms with the same 3-digit U.S. SIC code as the proxy for that industry. Source: Calculated by the authors using data from Compustat and CRSP; Raddatz (2006).

INVENTORIES/COGS: An alternative measure of liquidity needs. Similar to the previously described procedure, we use a 10-year window, $[t-10, t-1]$, for each crisis country to construct the index, where $t$ is the start year of the crisis. We first compute the ratio of inventories to the cost of goods sold for each U.S. manufacturing firm and obtain in each firm the median value of the ratio over its 10-year window. Then we take the median ratio across firms with the same 3-digit U.S. SIC code as the proxy for that industry. Source: Calculated by the authors using data from Compustat and CRSP; Raddatz (2006).

TRADE_CREDIT_RELIANCE: An alternative measure of liquidity needs that captures the industrial reliance on trade credit. Similar to the previously described procedure, we use a 10-year window, $[t-10, t-1]$, for each crisis country to construct the index, where $t$ is the start year of the crisis. We first compute the ratio of trade payable to the total debt for each U.S. manufacturing firm and obtain in each firm the median value of the ratio over its 10-year window. Then we take the median ratio across firms with the same 3-digit U.S. SIC code as the proxy for that industry. Source: Calculated by the authors using data from Compustat and CRSP; Fisman and Love (2003).

\section{Country-Level Characteristics}

GDP_PER_CAPITA: Natural logarithm of real GDP per capita measured at 3 years before the start year of a banking crisis. Source: World Development Indicators (WDI).

FINANCIAL_INSTITUTION_DEVELOPMENT: Private credit by deposit money banks and other financial institutions to GDP measured at 3 years before the start year of a banking crisis. Source: Čihák, Demirgüç-Kunt, Feyen, and Levine (2013).

STOCK_MARKET_DEVELOPMENT: Stock market capitalization to GDP measured at 3 years before the start year of a banking crisis.

PRIVATE_CREDIT_CONTRACTION: The average annual growth rate of bank credit over the precrisis period, $[t-3, t-1]$, minus the minimum annual growth rate of bank credit over the crisis period, $[t, t+3]$, where $t$ is the start year of a banking crisis. Source: Calculated by the authors using data from WDI.

CREDITOR_RIGHTS: A term that captures the power of creditors in bankruptcy and consists of four components: whether i) creditor approval is required before a debtor files for reorganization (reorganization restrictions)' ii) creditors are guaranteed to take possession of their collateral if the reorganization is approved (no automatic stay); iii) secured creditors are the first to get compensated from the liquidation proceeds (secured creditors first); and iv) an administrator assigned by either the creditors or the court, rather than the incumbent manager, is operating the firm in the process of reorganization (management does not stay). Each item takes the value of 1 when the answer is yes according to the bankruptcy and reorganization laws in a certain country. The overall index ranges from 0 to 4 , with higher values indicating more powerful creditor rights in the case of bankruptcy. Source: Djankov et al. (2007), La Porta et al. (1998). 
ANTI_SELF_DEALING: An index that represents the extent to which minority shareholders are protected by laws from being expropriated by the insiders. It equals the average of ex ante and ex post private control of self-dealing. The ex ante component is the average of permission of disinterested shareholders and ex ante disclosure requirements for the transaction purchasing company, the main owner of the selling company, and the independent review by a professional third party, whereas the ex post component is the average of requirements for periodic detailed disclosure on the transaction and the ease of proving wrongdoing. It ranges from 0 to 1 , with higher values indicating stronger minority shareholder protection against self-dealing transactions. Source: Djankov et al. (2008).

RULE_OF_LAW: The extent to which agents have confidence in and abide by the rules of society and, in particular, the quality of contract enforcement, property rights, the police, and the courts, as well as the likelihood of crime and violence. Source: World Bank, Kaufmann, Kraay, and Mastruzzi (2011).

INSTITUTIONAL_QUALITY: The first principal component of property rights and the six elements of Worldwide Governance Indicators, namely, voice of accountability, political stability and absence of violence, government effectiveness, regulatory quality, rule of law, and control of corruption. Property rights are defined as a score that measures the legal protection of people's privately owned property. The score ranges from 1 to 10, with higher values representing stronger property rights. Source: Calculated by the authors using data from World Bank, Kaufmann et al. (2011), Economic Freedom of the World (EFW) data sets, and the Fraser Institute.

LABOR_PROTECTION_LAWS: The strictness of regulation on dismissals of individuals or groups of workers. Specifically, it incorporates i) procedural impediments employers face when starting to fire workers, such as notification procedures; ii) the length of the notice period and the generosity of severance pay; iii) the difficulty of dismissal, as determined by the circumstances in which it is justifiable to fire a worker and the compensation and possibilities of reinstatement following unfair dismissal; and iv) additional costs and impediments to dismissing a large number of workers. The index ranges from 0 to 6 , with higher values indicating greater labor market protection. Source: OECD Employment Protection Database.

TRUST_IN_GOVERNMENT: The degree of confidence people have in the government. It is assessed by asking people the following question: "How much confidence do you have in the government: is it a great deal of confidence, quite a lot of confidence, not very much confidence or none at all?" For each nation, we calculate the average responses to this question as the level of trust in government. We use the level of trust at $t-3$, where $t$ is the start year of a banking crisis. Source: WVS. 


\section{References}

Allen, F.; J. Qian; and M. Qian. "Law, Finance, and Economic Growth in China.” Journal of Financial Economics, 77 (2005), 57-116.

Ayyagari, M.; A. Demirgüç-Kunt; and V. Maksimovic. "Formal versus Informal Finance: Evidence from China." Review of Financial Studies, 23 (2010), 3048-3097.

Ayyagari, M.; A. Demirgüç-Kunt; and V. Maksimovic. "Firm Innovation in Emerging Markets: The Role of Finance, Governance, and Competition." Journal of Financial and Quantitative Analysis, 46 (2011), 1545-1580.

Baker, M.; J. C. Stein; and J. Wurgler. "When Does the Market Matter? Stock Prices and the Investment of Equity-Dependent Firms.” Quarterly Journal of Economics, 118 (2003), 969-1005.

Beck, T.; A. Demirgüç-Kunt; and V. Maksimovic. "Financing Patterns around the World: Are Small Firms Different?” Journal of Financial Economics, 89 (2008), 467-487.

Beck, T.; R. Levine; and A. Levkov. "Big Bad Banks? The Winners and Losers from Bank Deregulation in the United States.” Journal of Finance, 65 (2010), 1637-1667.

Boyd, J. H.; S. Kwak; and B. Smith. "The Real Output Losses Associated with Modern Banking Crises." Journal of Money, Credit and Banking, 37 (2005), 977-999.

Campello, M.; J. R. Graham; and C. R. Harvey. "The Real Effects of Financial Constraints: Evidence from a Financial Crisis.” Journal of Financial Economics, 97 (2010), 470-487.

Carlin, B. I.; F. Dorobantu; and S. Viswanathan. "Public Trust, the Law, and Financial Investment." Journal of Financial Economics, 92 (2009), 321-341.

Čihák, M.; A. Demirgüç-Kunt; E. Feyen; and R. Levine. "Financial Development in 205 Countries." Journal of Financial Perspectives, 12 (2013), 1-19.

Claessens, S.; M. Kose; L. Laeven; and F. Valencia. Financial Crises: Causes, Consequences, and Policy Responses. Washington, DC: International Monetary Fund (2014).

Claessens, S.; H. Tong; and S. J. Wei. "From the Financial Crisis to the Real Economy: Using FirmLevel Data to Identify Transmission Channels." Journal of International Economics, 88 (2012), 375-387.

Cornett, M. M.; J. J. McNutt; P. E. Strahan; and H. Tehranian. "Liquidity Risk Management and Credit Supply in the Financial Crisis.” Journal of Financial Economics, 101 (2011), 297-312.

Djankov, S.; R. La Porta; F. Lopez-de-Silanes; and A. Shleifer. "The Law and Economics of SelfDealing." Journal of Financial Economics, 88 (2008), 430-465.

Djankov, S.; C. McLiesh; and A. Shleifer. "Private Credit in 129 Countries." Journal of Financial Economics, 84 (2007), 299-329.

Duarte, J.; S. Siegel; and L. Young. "Trust and Credit: The Role of Appearance in Peer-to-Peer Lending." Review of Financial Studies, 25 (2012), 2455-2484.

Fisman, R., and I. Love. "Trade Credit, Financial Intermediary Development, and Industry Growth." Journal of Finance, 58 (2003), 353-374.

Fukuyama, F. Trust: The Social Virtues and the Creation of Prosperity. New York, NY: Simon and Schuster (1995).

Garcia-Appendini, E., and J. Montoriol-Garriga. "Firms as Liquidity Providers: Evidence from the 2007-2008 Financial Crisis.” Journal of Financial Economics, 109 (2013), 272-291.

Gatev, E.; T. Schuermann; and P. E. Strahan. "Managing Bank Liquidity Risk: How Deposit-Loan Synergies Vary with Market Conditions.” Review of Financial Studies, 22 (2009), 995-1020.

Glaeser, E. L.; D. I. Laibson; J. A. Scheinkman; and C. L. Soutter. "Measuring Trust." Quarterly Journal of Economics, 115 (2000), 811-846.

Guiso, L.; P. Sapienza; and L. Zingales. "Long-Term Persistence.” Journal of European Economic Association, 14 (2016), 1401-1436.

Karlan, D. S. "Using Experimental Economics to Measure Social Capital and Predict Financial Decisions.” American Economic Review, 95 (2005), 1688-1699.

Kaufmann, D.; A. Kraay; and M. Mastruzzi. "The Worldwide Governance Indicators: Methodology and Analytical Issues." Hague Journal on the Rule of Law, 3 (2011), 220-246.

Klapper, L.; L. Laeven; and R. Rajan. "Trade Credit Contracts." Review of Financial Studies, 25 (2012), 838-867.

Knack, S., and P. Keefer. "Does Social Capital Have an Economic Payoff? A Cross-Country Investigation.” Quarterly Journal of Economics, 112 (1997), 1251-1288.

Kroszner, R. S.; L. Laeven; and D. Klingebiel. "Banking Crises, Financial Dependence, and Growth." Journal of Financial Economics, 84 (2007), 187-228.

La Porta, R.; F. Lopez-de-Silanes; A. Shleifer; and R. Vishny. "Trust in Large Organizations." American Economic Review, 87 (1997a), 333-338.

La Porta, R.; F. Lopez-de-Silanes; A. Shleifer; and R. Vishny. "Legal Determinants of External Finance." Journal of Finance, 52 (1997b), 1131-1150. 
La Porta, R.; F. Lopez-de-Silanes; A. Shleifer; and R. Vishny. "Law and Finance.” Journal of Political Economy, 106 (1998), 1113-1155.

Laeven, L. "Banking Crises: A Review." Annual Review of Financial Economics, 3 (2011), 17-40.

Laeven, L., and F. Valencia. "Systemic Banking Crises Database.” IMF Economic Review, 61 (2013), 225-270.

Levine, R.; C. Lin; and W. Xie. "Spare Tire? Stock Markets, Banking Crises, and Economic Recoveries." Journal of Financial Economics, 120 (2016), 81-101.

Love, I.; L. A. Preve; and V. Sarria-Allende. "Trade Credit and Bank Credit: Evidence from Recent Financial Crises." Journal of Financial Economics, 83 (2007), 453-469.

Ng, C. K.; J. K. Smith; and R. Smith. "Evidence on the Determinants of Credit Terms Used in Interfirm Trade." Journal of Finance, 54 (1999), 1109-1129.

Nunn, N., and L. Wantchekon. "The Slave Trade and the Origins of Mistrust in Africa." American Economic Review, 101 (2011), 3221-3252.

Pagano, M., and P. Volpin. "Labor and Finance." Working Paper, London Business School (2008).

Putnam, R. D. Bowling Alone: The Collapse and Revival of American Community. New York, NY: Simon and Schuster (2000).

Raddatz, C. "Liquidity Needs and Vulnerability to Financial Underdevelopment." Journal of Financial Economics, 80 (2006), 677-722.

Rajan, R. G., and L. Zingales. "Financial Dependence and Growth." American Economic Review, 88 (1998), 559-586.

Reinhart, C. M., and K. Rogoff. This Time Is Different: Eight Centuries of Financial Folly. Princeton, NJ: Princeton University Press (2009).

Tabellini, G. "Culture and Institutions: Economic Development in the Regions of Europe." Journal of the European Economic Association, 8 (2010), 677-716.

Williamson, O. E. "The New Institutional Economics: Taking Stock, Looking Ahead." Journal of Economic Literature, 38 (2000), 595-613. 